\title{
THE RULE OF LAW IN THE EU: BETWEEN UNION AND UNITY
}

\author{
Franco Peirone *
}

\begin{abstract}
The use of Article 7 TEU against Poland and Hungary has been generally welcomed with relief, proving that, at last, the EU is ready to defend Article 2 TEU values when Member States openly violate them. However, it is not clear yet what the main value that is claimed to be breached - the rule of law - amounts to in the EU. Actually, the resort to Article 7 TEU crowns a process of equipping the EU with a rule of law framework to combat Member States' failures in both law making and enforcement, regardless of the law's content and provenance. This article demonstrates that the EU rule of law is anchored to a 'thin' conceptualisation of the ideal and that the EU is moving from a mere rule of EU law towards a more sophisticated EU rule of law perspective. This process is, at the same time, enlarging the boundaries of the EU legal order and reaffirming the Union character - and not Unity only - of EU integration through law.
\end{abstract}

Keywords: EU values, EU law, rule of law, rule of law crisis, compliance

\section{Introduction}

The core of EU integration as an 'ever closer union among its peoples'l relies on the progressive unification of the Member States' legislations. This process is carried out through the law, by EU legal instruments with replacing or harmonising effects, whose ultimate purpose is the integration of the law. ${ }^{2}$ However, along with the unification of Member States' legislations in more and more areas, the other grand expectation was that the EU, as a supranational entity founded on the value of the rule of law, ${ }^{3}$ would provide an additional guarantee that the Member States' unlawful actions be emended. ${ }^{4}$ Particularly, the EU commitment

\footnotetext{
" Lecturer in European and Constitutional Law, Maastricht University, orcid.org/00000002-6760-0452. DOI: 10.3935/cyelp.15.2019.344.

1 Article 1(2) TEU.

2 Mauro Cappelletti, Monica Seccombe and Joseph HH Weiler, Methods, Tools, and Institutions, Integration Through Law: Europe and the American Federal Experience, vol 1 (De Gruyter 1986).

3 Article 2 TEU, Article 21(1) TEU, Preamble of the EU Charter of Fundamental Rights.

4 András Jakab and D Kochenov, 'Introductory Remarks' in András Jakab and Dimitry Kochenov (eds), The Enforcement of EU Law and Values: Ensuring Member States' Compliance (OUP 2017) 1.
} 
to the rule of law was proving that the very fabric of the law would be clear and sound, and that the EU itself would be the guardian of the law, not just EU law, but the law independently of its content, provenance or effect.

Recently, two countries, Hungary and Poland, belonging to the former Eastern bloc and now members of the Union, have dramatically challenged this aspiration. Their actions have disturbed these EU rule of law premises and horizon, triggering 'rule of law crises'. ${ }^{5}$ However, the list of Member States whose legal systems harm the EU rule of law is not static. It encompasses different countries at different moments: different rule of law crises take place. Problems with law making and its enforcement also occur in countries with long-standing democracy traditions and they potentially affect any Member States. ${ }^{6}$

Indeed, while a rule of law crisis is relatively easy to denounce, it is not clear yet what a rule of law violation in the EU legal order amounts to. And while there is a huge literature on Member States' departures from Article 2 TEU values - "rule of law backsliding"7 - there is significantly less on what they depart from, namely the meaning of Article 2 TEU values, and particularly the rule of law, from an EU purview. This article aims then to answer the questions of why, how and to what extent the EU has taken the role of guardian of the law by examining and systematising the outcomes of EU efforts to tackle rule of law violations for approximately twenty years. ${ }^{8}$ This analysis will clarify what is sanctioned and why it is sanctioned, thus drawing the boundaries of the EU rule of law.

\footnotetext{
5 Viviane Reding, 'The EU and the Rule of Law - What Next?' (Speech, Centre for European Policy Studies, Brussels, 4 September 2013).

6 Frank Hoffmeister, 'Enforcing the EU Charter of Fundamental Rights in Member States: How Far Are Rome, Budapest and Bucharest from Brussels?' in Armin Von Bogdandy and Pal Sonnevend (eds), Constitutional Crisis in the European Constitutional Area: Theory, Law and Politics in Hungry and Romania (Hart Publishing 2015) 195.
}

7 R Daniel Kelemen, 'Is Differentiation Possible in Rule of Law?' (2019) Comparative European Politics 17; Kim Lane Scheppele, 'Autocratic Legalism' (2018) University of Chicago Law Review 549; Laurent Pech and Kim Lane Scheppele, 'Illiberalism Within: Rule of Law Backsliding in the EU' (2017) 19 Cambridge Yearbook European Legal Studies 3.

8 This article examines, then, the rule of law only from this narrow perspective; for more comprehensive works on the EU and the rule of law, and for other purviews and perspectives, see: Paul Blokker, 'EU Democratic Oversight and Domestic Deviation from the Rule of Law: Sociological Reflections' in Carlos Closa and Dimitry Kochenov (eds), Reinforcing Rule of Law Oversight in the European Union (CUP 2016) 249; Gianluigi Palombella, 'Beyond Legality - Before Democracy: Rule of Law Caveats in the EU Two-Level System' in Carlos Closa and Dimitry Kochenov (eds), Reinforcing Rule of Law Oversight in the European Union (CUP 2016) 36; Laurent Pech, 'Promoting the Rule of Law Abroad: On the EU's Limited Contribution to the Shaping of an International Understanding of the Rule of Law' in Dimity Kochenov and Fabian Amtenbrink (eds), The European Union's Shaping of the International Legal Order (CUP 2013) 108; Laurent Pech, 'The Rule of Law as a Constitutional Principle of the European Union' (2009) 4(9) NYU Jean Monnet Working Paper 1. 
In conclusion, this development will be examined as the EU achievement of a task of oversight of how the Member States legislate and enforce the law. This will demonstrate that an EU conception of the rule of law alongside that of the rule of EU law - has emerged, and the EU project itself lies in an equilibrium of the two principles of unity and union.

\section{The EU institutional framework and background on the rule of law matter}

There is no doubt that the rule of law has always been a foundational value for the EU, despite it not having been explicated from the beginning. The need for a clear statement in this regard, as well as for a mechanism to ensure compliance with EU values such as the rule of law, has been a recent issue in EU integration. ${ }^{9}$

Until the Eastwards Enlargement, the EU Member States shared, or believed they shared, a like-minded approach to the rule of law, together with human rights and democracy, which could never be suppressed. In the worst-case scenario, national institutions were expected to swiftly rebut any attempt to infringe upon them. Moreover, the European Court of Human Rights, to which all the Member States were party, had been unofficially entrusted to deal with the rule of law, human rights and democracy in Member States, where the EU was mainly an economic enterprise at that time. ${ }^{10}$ The pending enlargement with countries once belonging to the Communist bloc, and the EU's evolution towards a fully political union, propelled by the Maastricht Treaty of 1992 that inserted human rights and democracy in its Preamble, put these values at the centre of the EU's agenda. ${ }^{11}$

More in detail, in the European Council Conclusions of 21-22 June 1993, the rule of law was declared a requirement that any State that wishes to accede to the EU must meet. ${ }^{12}$ The political criterion for ad-

\footnotetext{
9 Dimitry Kochenov and Laurent Pech, 'Better Late than Never? On the European Commission's Rule of Law Framework and its First Activation' (2016) 54(5) Journal of Common Market Studies 1064.

10 Gráinne De Búrca, 'Beyond the Charter: How Enlargement Has Enlarged the Human Rights Policy of the European Union' (2004) 27 Fordham International Law Journal 683.

11 Madrid European Council, 15-16 December 1996, Presidency Conclusion, Part A, Introduction.

12 Ronald Janse, 'Is the European Commission a Credible Guardian of the Values?: A Revisionist Account of the Copenhagen Political Criteria during the Big Bang Enlargement' (2019) 17(1) International Journal of Constitutional Law 43; Christophe Hillion, 'The Copenhagen Criteria and Their Progeny' in Christophe Hillion (ed), EU Enlargement: A Legal Approach (Hart Publishing 2004) 17; Mark Marceau, 'Pre-accession', in the Enlargement of the European Union' in Marise Cremona (ed), The Enlargement of the European Union (OUP 2003) 9.
} 
mission to the EU requested indeed the 'stability of institutions guaranteeing democracy, the rule of law, human rights and respect for and protection of minorities'. ${ }^{13}$ In the admission procedure, the rule of law today plays an important role, being treated as a separate chapter in all the Reports elaborated by the Commission, which refer to the level of negotiations with each Applicant State, and accordingly to Article 49 TEU, which codified the 'Copenhagen criteria' as one of the values that need to be respected for admission.

Further in this process, the principles or values on which the Union was founded were first listed in the Amsterdam Treaty of 1996 in the Preamble and in Article 6, confirmed in the Treaty of Nice of 2001, and, last, provided in the Treaty of Lisbon of 2009 in Article $2 .{ }^{14}$ All these values - namely respect for human dignity, freedom, democracy, equality, the rule of law and respect for human rights, including the rights of persons belonging to minorities - are expressly common to the Member States and to the EU, to the extent that they represent the constitutional identity of the EU itself. ${ }^{15}$ The EU, and its institutional framework, is bound not only to ensure but also to promote these values, ${ }^{16}$ and Member States are equally bound to assist the EU in carrying out these tasks. ${ }^{17}$ To ensure that these values are respected, the Amsterdam Treaty provided, in Article 7, a sanctioning mechanism against the Member States that violated them. ${ }^{18}$

\section{The early depoliticisation and institutionalisation of a rule of law crisis}

Considering the EU institutional framework briefly sketched, what are the conditions for denouncing a rule of law crisis in the EU, and what are the core elements of the rule of law concept in the EU that is allegedly threatened?

With regard to the first question, the preliminary condition the EU requires now is the presence of a Member State action. This means that a Member State has to undertake an action and this action has to be considered to go against the EU rule of law concept, and not simply to be condemnable by a political purview. This assumption derives from the

13 European Council, Presidency Conclusions, Copenhagen, 21-22 June 1993.

14 Gráinne De Búrca, 'Beyond the Charter: How Enlargement Has Enlarged the Human Rights Policy of the European Union' (2003) 27(2) Fordham International Law Journal 696.

15 Wojciech Sadurski, 'European Constitutional Identity?' (2006) 33 EUI Working Paper Law 2.

16 Article 3(1) TEU and Article 13(1) TEU.

17 Article 4(3) TEU.

18 Now Article 7(2) TEU. 
outcomes of the Austria crisis of 2000, which is to be held the first rule of law crisis in the EU and the first EU intervention in one Member State's legal and political situation. ${ }^{19}$

The Austria crisis took place when, after a national election, a coalition Government was sworn in, whose junior party was the far right and xenophobic FPÖ, led by the notorious Jorg Haider. ${ }^{20}$ Worried about the rise of a right-wing Government within the EU, the Council, under its Portuguese presidency, issued a general statement on behalf of the other 14 EU Member States - but not in the name of the EU as such - which provided for the suspending of contact with Austrian Government officials, the withdrawal of EU support for Austrian applications for positions in international organisations, and the ceasing of contact with the Austrian Ambassadors, except at a technical level. ${ }^{21}$ These sanctions came into effect on 4 February 2000, once the Austrian Government officially took power. The solution adopted here was surely not an EU initiative as such, either in its content - being traditionally bilateral measures of public international law - or in its provenance, coming from 14 Member States from a classic intergovernmental coordination perspective. ${ }^{22}$ The sanctions were maintained under the French Presidency of the second semester of 2000. However, on 29 June 2000, the 14 EU Member States together decided to appoint a committee to examine the Austria case,

19 Konrad Lachmayer, 'Questioning the Basic Values - Austria and Jörg Haider' in András Jakab and Dimitry Kochenov (eds), The Enforcement of EU Law and Values: Ensuring Member States' Compliance (OUP 2017) 436; Jan-Werner Mulller, 'The EU as a Militant Democracy, or: Are There Limits to Constitutional Mutations within EU Member States?' (2014) Revista de Estudios Politicos 149; Bojan Bugari, 'Protecting Democracy and the Rule of Law in the European Union: The Hungarian Challenge' (2014) 79 LESQ Paper 5; Wojciech Sadurski, 'Adding a Bite to a Bark? A Story of Article 7, the EU Enlargement, and Jörg Haider' (2010) Columbia Journal of European Law 385; Heather Berit Freeman, 'Austria: The 1999 Parliamentary Elections and the European Union Member's sanctions' (2002) 25 Boston College International \& Comparative Law Review 109; Michael Merlingen, Cas Mudde and Ulrich Sedelmeier, 'The Right and the Righteous? European Norms, Domestic Politics, and the Sanction against Austria' (2001) 39 Journal of Common Market Studies 59.

20 The crisis started in 1999, when the far-right party FPÖ (Austrian Freedom Party) gained 26.91 percent in the general election, and became the second most popular political party in the country. The FPÖ, together with the more moderate OVP (Austrian People's Party), started negotiations to form a Government on 25 January 2000, which was finally sworn in on 3 February and took power on 5 February 2000. The new Government was a Coalition Government, where the Chancellor came from the OVP, and Haider was not even part of the Cabinet; however, the Deputy Chancellor came from the FPÖ, and several important ministries, such as Finance, Justice and Defence, were covered by FPÖ Members.

21 Statement of the Portuguese Presidency of the European Union on behalf of the XIV Member States of 30 January 2000 in Bulletin Quotidien Europe No 7654 of 31 January 2000, 9.

22 However, the action fell not entirely outside the EU's influence: the statement was written on official stationery of the Council Presidency; the Commission (EU Commission, Declaration 1 February 2000, IP/00(93) and the EU Parliament (EU Parliament, Resolution of 3 February 2000, PE 284.656, paras 2 and 8) added their voices, too. 
and its compliance with EU values, in more detail. It was decided that, should Austria be in compliance with EU standards, the sanction would be withdrawn. The Report - by three experts appointed by the European Court of Human Rights at the Council's request ${ }^{23}$ - was divided into two parts, regarding the Austrian Government's commitment to EU values and the political nature of the FPÖ. Predictably, the Report did not find any violation of EU values in the Austrian Government's activities, ${ }^{24}$ and was in favour of lifting the sanctions. ${ }^{25}$ Consequently, on 12 September 2000, the French Presidency withdrew the sanctions against Austria.

The intervention legitimacy was quite doubtful. The sanctions adopted were exclusively grounded on the basis of the FPÖ and Haider's past pronouncements rather than the Government's actions. Actually, the situation in Austria, the swearing in of a new Government, clearly did not meet the conditions for actuating Article 7 of the Treaty. There had been no serious and persistent breach of the rule of law, nor could there have been, since the Government had not yet been active. Even if there had been, no proof of these breaches was brought by the interested parties. Another problematic issue was that Austria was practically denied the right to be heard. ${ }^{26}$ The intervention also lacked legitimacy in a broader sense. The EU institutions seem to have been dragged into the struggle, as had the smaller EU countries, and had not been consulted promptly by the Member States who took the lead. The initiative clearly assumed a political streak, being decided by like-minded heads of big States. Conclusively, it had the character of a fait accompli with strong political overtones. These two different concerns seriously questioned the legitimacy of the intervention in the Austria crisis and marked the EU attitude to future rule of law crises. ${ }^{27}$

Firstly, with regard to resorting to public international law sanctions such as the ceasing of contact with a Member State ambassador,

23 Martti Ahtisaari, former President of Finland; Jochen Frowein, director of the Max Planck Institute for Comparative Public Law and International Law; Marcelino Oreha, former Spanish Minister for Foreign Affairs were appointed on 12 July 2000 by the President of the ECtHR. See ECtHR, Press Release no 491, 29 June 2000.

24 Report by Martti Ahtisaari, Jochen Frowein and Marcelino Oreha, 108-109. The Report was more sceptical, even if not radically so, about the democratic and pluralist credentials of the FPÖ, 110-113.

25 Kathrin Blanck, 'Austria: Between Size and Sanctions' in Finn Laursen (ed), The Treaty of Nice: Actor Preferences, Bargaining and Institutional Choice (Martinus Nijhoff Publishers 2005) 28.

26 Leonard Besselink, 'The Bite, the Bark and the Howl: Article 7 TEU and the Rule of Law Initiatives' in András Jakab and Dimitry Kochenov (eds), The Enforcement of EU Law and Values: Ensuring Member States' Compliance (OUP 2017) 129.

27 Gerda Falkener, 'The EU14's “Sanctions" against Austria: Sense and Nonsense' (2001)

12 CSA Review, Journal of the European Union Studies Association 14-15. 
they were not used in this way anymore. A common perception emerged that to resort to traditional public international law sanctions was out of place in the EU, and with regard to such delicate issues. It calls to mind a past world of political calculation and the prevalence of politics over law. ${ }^{28}$ Depoliticisation regarded not only the tools employed, but also the Member State actions that were questioned. Putting it simply, Austria had violated neither EU law nor the rule of law in general, or at least it did not do so simply by having a junior Government party which had certain questionable positions in its ideological background. The following crisis focused instead on actual rule of law violations or risks of violation, and no longer political affiliation. Rule of law violations could not be determined on political grounds alone, but need a consequent Government action. So, a violation or a risk of a violation should have actually occurred: a necessary condition for an intervention is the existence of a track record of violating the rule of law.

From the crisis, the need also arose to consolidate and reframe the Article 7 TEU procedure. On one hand, the expert report affirmed the need for an open and non-confrontational dialogue with the Member State concerned, so as to remedy the lack of audita altera parte. ${ }^{29}$ On the other hand, the EU Parliament had invoked a more expedited track for tackling rule of law violations even if they do not reach the threshold of serious and persistent breaches. ${ }^{30}$ The EU then provided a preventive mechanism alongside the sanctioning mechanism in Article 7 within the Nice Treaty of 2001, and granted that the concerned Member State government be heard in both the procedures. ${ }^{31}$ The Rule of Law Framework of 2014 has completed this progressive institutionalisation of the reaction tools vis-à-vis a rule of law crisis, which now follows a precise procedural sequence. ${ }^{32}$

\footnotetext{
28 For example, despite the fact that several countries have advocated for implementing the tools for stopping the crisis in Hungary - see the joint letter of the Foreign Ministers of Denmark, Finland, Germany and the Netherlands to the Commission on 6 March 2013 - they have pushed the Commission to act through a legitimate procedure rather than operating independently. By doing so, the political character of the initiative was cooled off, since it was the institutional EU organ that was operating and not the Governments of other Member States.

29 Letter from the Representative of Austria at the Conference of Representatives of the Governments of the Member States to J Solana, Secretary-General, High Representative, IGC 2000: Draft Amendments to Article 7 and 46 of the TEU, Conference of the Representatives of the Governments of the Member States, CONFER 4712/00, Brussels, 15 February 2000.

30 EU Parliament, Resolution containing the European parliament's proposal for the Intergovernmental Conference of 13 April 2000, A5-0086/2000.

31 Now Article 7(1) TEU.

32 EU Commission, A new EU Framework to strengthen the Rule of Law COM(2014) 158 Final.
} 


\section{Defining the scope of the breach and EU intervention: from the rule of EU law to the EU rule of law}

Once acknowledged that for a rule of law crisis, government action was necessary, it has long been unclear - and it is still being debated what the scope of the possible actions targeted is and, consequently, the scope of EU intervention. It was a crucial matter whether only Member State actions breaching EU legislation could be targeted, or, more broadly, any Member State action in breach of the rule of law.

The different sets of actions of Silvio Berlusconi's governments in Italy during the periods 2001-2006 and 2008-2011 may offer an interesting clarification in this regard. Berlusconi's appointment as prime minister brought at least two dangerous situations to the rule of law: firstly, he was under investigation, and was standing trial, for several crimes; secondly, he was a public service concessionaire entrusted with half of all the television channels in Italy. His rise to political power made the public fear that he would bend legislative power to escape criminal justice and favour his position as concessionaire. ${ }^{33}$ During his governments, Berlusconi was able to adopt a series of laws that had the purpose of helping him in his ongoing trials. These laws were nicknamed ad personam because they were clearly directed at guaranteeing Berlusconi's personal interests rather than to ensure any public good. ${ }^{34}$

In particular, the law of 20 June 2003, n 140, which provided absolute immunity from criminal prosecution for the president of the Republic, the prime minister, the presidents of the two Chambers and the Constitutional Court, was held unconstitutional, mostly for violating the principle of equality in Article 3 of the Italian Constitution. ${ }^{35}$ Berlusconi proposed a similar legislative attempt to escape his ongoing trial once more when, during his last return to the government (2008-2011), he

\footnotetext{
33 Council of Europe, European Commission for Democracy Through Law, CDL$\mathrm{AD}(2013) 038$.

34 Interestingly, the ad personam laws were of two different types. Some were clearly framed in such a way that the persons concerned and the interest ensured could only have been Berlusconi and his own assets. For example, the government sought to provide the prime minister with immunity from prosecution. It was clear that only Berlusconi himself would have benefited from the law - being the prime minister at that time - and that that law was exclusively made for his personal purposes - since the need for such immunity had never been felt compelling before. Other laws were, however, enacted with a general scope of application, and in principle serving a general purpose but de facto, on account of their timing and circumstances, serving only, or mostly, Berlusconi's interests. For example, no one can deny that a more lenient treatment for certain crimes could have been of general interest. However, it was also difficult not to see Berlusconi's interest prevailing over any legislative consideration when the law enacted - for abolishing the crime or modifying the statute of limitations - related precisely to the crimes for which he was on trial.
}

35 Corte Costituzionale, 20 January 2004, n 24, and later 19 November 2007, n 380. 
reframed the previous law in accordance with the Constitutional Court's remarks, excluding the president of the Constitutional Court from the shielded position this time, in the law of 23 July 2008, n 124. However, this law was also declared unconstitutional for violation of the principle of equality. ${ }^{36}$ Tenaciously, Berlusconi made a third attempt - this time providing the government ministries with the capacity to refuse to appear before the court because of their governing function - to shield himself from the ongoing trials, counting on the delays to have the process lapsed by the statutes of limitations, with the law of 7 April 2010, n 51. Again, the law was partially dismantled by the Constitutional Court, ${ }^{37}$ and entirely by the outcome of the popular referendum of 12-13 June 2011. It could be concluded that even serious rule of law crises, such as where legislative power is grasped by the government and bent to serve individual purposes, could be resolved without the intervention of the EU: in certain situations, national institutions, such as constitutional courts, parliaments, but public opinion too, are strong enough to deal with the crisis. ${ }^{38}$ The success of a national legal order in resolving a crisis means that the crisis itself has not reached the threshold of seriousness that would alarm the EU, and triggered its rule of law tools.

Another series of ad personam laws followed a different path. Here, Berlusconi aimed at reducing penalties for crimes such as falsification of books, and consequently a reduction of the statute of limitations, crimes with which he was charged at that time. The revision of company legislation substantially served the prime minister's interests since it reduced the penalty for publishing false documents with a consequent decrease of the terms of imprisonment from up to five years to less than two years. ${ }^{39}$ Furthermore, the statute of limitation period decreased from ten years to four and a half years. Here, an intervention of the Italian Constitutional Court could not have readdressed the situation, since the ground of equality, being the law treating everyone equally, was not violated. Thus, an Italian ordinary court made a preliminary reference to the CJEU, asking if the sanctions introduced by the new law, in consideration of the recent legislative amendments, could still be held as effective, proportionate and dissuasive, as requested by the EU law for company law. ${ }^{40}$ The CJEU did not find any ground to question the Italian law: despite

\footnotetext{
36 Corte Costituzionale, 7 October 2009, n 262.

37 Corte Costituzionale, 13 January 2011, n 23.

38 Carlos Closa, Dimitry Kochenov and Joseph HH Weiler, 'Reinforcing Rule of Law Oversight in the European Union' (2014) 25 Robert Schuman Centre for Advanced Studies Research Paper.

39 Law 3 October 2001, n 366; Legislative Decree, 11 April 2002, n 61.

40 First Council Directive 68/151/EEC of 9 March 1968, Fourth Council Directive 78/660/ EEC of 25 July 1978 and Seventh Council Directive 83/349/EEC of 13 June 1983.
} 
their dubious effectiveness, the new provisions were recognised as applicable on the basis of the principle of the retroactive application of a more lenient penalty. The CJEU considered that, although the new provisions could be in breach of the EU Directive, the national courts could not avoid applying them, as the Directive would otherwise have a direct effect on individuals, increasing their criminal liability ${ }^{41}$ Therefore, Berlusconi was acquitted during the following trial in Italy in September 2005 , since the date of the acts that underlay the alleged crimes was before the expiry of the shortened limitation period.

Interestingly, the $\mathrm{EU}$ as a whole, and the CJEU in particular, is perceived to be the last instance of inquiring into the legality of law, even where the connection between EU law and national law is not so evident. After all, in the CJEU mandate to ensure that 'the law is observed' pursuant to Article 19 TEU, there is no precise evidence of which law. In particular, the preliminary ruling is employed for assessing the compatibility of the national law with EU law, forming a tool for evaluating the legality of national law. ${ }^{42}$ Here, the preliminary ruling is a substitute for the infringement procedure, providing an indirect enforcement of $\mathrm{EU}$ law. ${ }^{43}$ Indeed, despite the fact that the CJEU is not competent to invalidate a national law, its interpretative mechanism allows it to model the question so that it reads as if the EU law precludes a conflicting national law. If so, the Member State is obliged to amend the national law. What is of utmost importance is that the erga omnes effects of preliminary rulings means that when interpreting EU law, all national courts are obliged to apply not only the operative part of a preliminary ruling, but also its ratio. ${ }^{44}$ From this perspective, the preliminary ruling ensures a rule of law custom of obedience to the CJEU ruling by the State. ${ }^{45}$ In this way, the EU overcomes the traditional weakness of the rule of law on the international plane: the EU supranational system puts the inherently stronger national systems in the service of the supranational order. ${ }^{46}$

A third type of rule of law breach in Berlusconi's government could be located in his other conflict of interests: being a public service concessionaire, there were issues with regard to his use of governmental

41 Case C-387/02 Berlusconi and others ECLI:EU:C:2005:270, paras 68-69.

42 Paul P Craig, 'Once Upon a Time in the West: Direct Effect and the Federalization of EEC Law' (1992) 12(4) Oxford Journal of Legal Studies 453, 454-456.

43 Case C-231/06 Jonkman ECLI:EU:C:2007:373, para 36.

44 Case C-260/89 Elliniki Radiophonia Tiléorassi ECLI:EU:C:1991:254, paras 24-26.

45 Joseph HH Weiler, 'The Community System: The Dual Character of Supranationalism' (1981) 1(1) Yearbook of European Law 301.

46 Joseph HH Weiler, 'Van Gend en Loos: The Individual as Subject and Object and the Dilemma of European Legitimacy' (2014) 12(1) International Journal of Constitutional Law 96. 
legislative and executive powers for the sake of his business goals. In the name of the principle of pluralism in a democratic society, the Constitutional Court had declared that Berlusconi, as a media entrepreneur, was required to give up one of his three national television channels. However, he neither complied with any of these judgments, nor did the government, which was at his disposal, make any attempt to force it. ${ }^{47}$

Here, the European Parliament expressed its concerns about the Italian situation, calling for the European Commission to submit a proposal for a Directive to safeguard media pluralism - so enabling a possible infringement action for an EU law violation, and to consider the use of Article 7 TEU on the consideration that a free and pluralist media landscape reinforces democracy, which is a foundational EU value. ${ }^{48}$ Thus, the EU Parliament identified the grounds for acting on the link between pluralism and democracy. These were, however, general grounds, being merely principles, not underpinned by any EU specific legislation, which could have authorised the Commission to act on the infringement procedure instead. However, even if in vague terms, the European Parliament also identified a possible rule of law ground, entirely based on the rule of law principles. In fact, Parliament highlighted its deep concern in relation to the non-application of the law and the non-implementation of judgments of the Constitutional Court, in violation of the principle of legality and the rule of law'. ${ }^{49}$

The EU Parliament thus affirmed that an action could have taken place not only in the name of media pluralism but also directly on a rule of law ground: that the Italian rulings were ignored, and therefore the law, as declared by the Constitutional Court, was not enforced. Thus, in the EU rule of law debate, there is also a concern regarding the enforcement of the law per se, no matter if underpinned by a particular EU law - non-existing at that time with regard to the media regulation - or with direct relevance to democracy or human rights. These considerations are not necessary: simply put, not implementing national laws or judgments is of concern for the EU, not only for Member States. ${ }^{50}$ The

\footnotetext{
47 Corte Costituzionale, 20 November 2002, n 466 and 7 December 1994, n 420.

48 European Parliament Resolution of 22 April 2004 on the risks of violation, in the EU and especially in Italy, of freedom of expression and information [2004] OJ C104E, paras 76 and 83-84.

49 ibid, para 66.

50 In all legal systems, there are sporadic violations in law-making and its enforcement. Nevertheless, a threshold exists after which a society is no longer ruled by the law, in both senses of forming a legal framework for the community (law-making) and taking actions in accordance with the same legal framework (enforcement). In this scenario, customised and case-by-case driven economic considerations determine the normative relationships. Law is just window-dressing (with respect to law-making) or a misleading prospect (with respect to enforcement).
} 
whole situation, however, came to an unsatisfactory close when the Italian government adopted the law of 3 May 2004, n 112, through which the whole media system was reformed. Thanks to the effects of the reform, Berlusconi could keep his channel, frustrating the Constitutional Court judgment and the EU Parliament initiative.

With regard to the scope of the actions questioned, it seems, then, that the EU targets, even if not always successfully as proven in this latter case, two different state activities that could be understood according to their functions with regard to the law. These functions are law-making and the enforcement of law and are clearly distinguishable in any legal system: creating the law is one thing, applying it is another. The former concerns how the law is made, what the law openly affirms; the second, instead, regards how the law is enforced, and what its implementation is for society. According to the Rule of Law Framework, ${ }^{51}$ indeed, the core elements of the rule of law for the EU are the six requirements of: legality, as the process for enacting law; legal certainty; prohibition of arbitrariness of the executive powers; independent and impartial courts; effective judicial review, including respect for fundamental rights; equality before the law. ${ }^{52}$ These principles regard both law-making and its enforcement. Some of them, such as legal certainty and prohibition of arbitrariness, are clearly linked to a rule of law enforcement side. This means that the rule of law not only implies the institutional limits of powers - how the law should be framed - but also the effectiveness of the ruling - that the law should be enforced. ${ }^{53}$ Without legal certainty and prohibition of arbitrariness - considering that arbitrariness could also include the non-application of relevant law ${ }^{54}$ the rule of law would be incomplete. ${ }^{55}$

Starting with the state law-making activity, a law that fails to comply with the requirements of being a law is simply a failure in law-making and is wrong in itself. ${ }^{56}$ The symptoms of this failure can be found in the same framing of the law that denounces itself as violating the

\footnotetext{
51 Commission, Communication to the European Parliament and the Council, 'A new EU Framework to strengthen the Rule of Law' COM(2014) 158 final.

52 ibid, para 2.

53 Margaret Jane Radin, Reconsidering the Rule of Law' (1989) 69 Boston University Law Review 785-786.

54 Elisabeth Steiner, The Rule of Law in the Jurisprudence of the European Court of Human Rights' in Werner Schroeder (ed), Strengthening the Rule of Law in Europe: From a Common Concept to Mechanism of Implementation (Hart Publishing 2016) 149; Javier Corrales, 'Autocratic Legalism in Venezuela' (2015) 26 Journal of Democracy 38.

55 Gabor Attila Tòth, 'Illiberal Rule of Law? Changing Features of Hungarian Constitutionalism' in Maurice Adams, Anne Meuwese and Ernst Hirsch Ballin (eds), Constitutionalism and the Rule of Law: Bridging Idealism and Realism (CUP 2017) 402.

56 Joseph Raz, 'The Law's Own Virtue' (2018) Tang Prize Lecture 8.
} 
rule of law. The law does not serve collective purposes if it is clearly and unduly directed towards only certain individuals; the law is retroactive in regularising or modifying a certain situation in bad faith; the law is obscured or, more frequently, its outcomes are hidden, unpredictable, or unclear; the law itself is unclear; the law is transitory or unstable; the law is contradictory, leaving discretion of implementation entirely to the enforcement or public officials or other bodies, like a blank check.

What, then, are the parameters for judging law-making? In national legal systems, this is the province of constitutional law, and a constitutional court affair. Constitutional courts assess the compatibility of law-making with their constitutions, which demand that the law is created according to certain parameters. From the EU perspective, circumstances help to find failures in Member States law-making Timeliness (or untimeliness), lack of parliamentary debate, recourse to accelerated procedures, and over-constitutionalisation ${ }^{57}$ are classic procedural symptoms that point towards the existence of failure in law-making. ${ }^{58}$ The procedural virtutes in legislation, or legislative due process, ${ }^{59}$ are the guarantees of the rule of law, fundamental to the aim that the law will comply with its formal requirements. ${ }^{60}$ Generality, prospectivity, predictability, etc, will be genuinely framed by law-makers and accepted by citizens to the extent that the legislative process is respectful of certain procedural requirements. Thanks to the supremacy principle, the EU is indifferent to what kind of source of law or type of legislation is at stake in a rule of law crisis. It could be parliamentary law, law decrees, ministerial decrees, administrative practices or any other Member State action. Even constitutional law does not escape its grasp. The only type of situation where the EU does not seem to operate anymore is the one where no current action is taken (yet), as was the case in the Haider affair.

Failure in enforcement of the law is slightly different as it regards a much bigger area. It could possibly concern all laws, also ones that comply with the rule of law's formal requirements, which are infinitely more numerous than the failing ones. All situations where a challenge to the

57 David Landau, 'Abusive Constitutionalism' (2013) 47 UC Davis Law Review 199.

58 As Waldron argues, bicameralism, checks and balances, the formality and solemnity of the treatment of bills in the Chambers, the publicity of legislative debates, the time for consideration, formal and informal, internal and external to the legislature are all elements which compose legislative due process that are central in the procedural conception of the rule of law for the safety of the legislation as the rule of law. Jeremy Waldron, 'Legislation and the Rule of Law' (2015) 1(1) Legisprudence 107.

59 Stephen Gardbaum, 'Due Process of Lawmaking Revisited' (2018) 18(12) UCLA Public Law Research Paper 7.

60 Wojciech Sadurski, 'How Democracy Dies (in Poland): A Case Study of Anti-Constitutional Populist Backsliding’ (2018) 18(01) Legal Studies Research Paper 46. 
rule of law is not apparent, but which regards its correct implementation or effective enforcement, fall within this area. A failure in the enforcement of the law is never legal: it is reprehensible in any legal system. ${ }^{61}$ The rule of law exploits all its significance in having the law respected once it is in force. This type of failure strikes the rule of law in particular, and, even more dramatically, the EU rule of law, even more than failure in law-making.

This because the EU relies on the administrative apparatus of Member States. The enforcement of EU law is delegated to the Member States. Sanctioning is in the hands of the Commission, but ordinary compliance remains with national public administrations. The EU has only limited capacity in directly implementing its own law: the human, fiscal and management resources needed for the implementation are borrowed from the Member States. However, what is left to Member States in the matter of application must be severely controlled and sanctioned. It is clear that the EU institutions should fight failure in enforcement harder because it is the responsibility of Member States to enforce the rule of law. If Member States do not have the ability to implement EU law, EU law's effectiveness is jeopardised. When this happens, the EU must intervene: it is on this presumption that the whole EU and EU rule of law is based. This explains why all the tools at the disposal of the EU are exceptional and should be unlocked only in grave situations. They represent a last resort for the EU supranational normative ideal. Therefore, while law-making can be freely exercised in certain areas of the EU, law enforcement cannot. It should be the same in the whole EU. Equal, fair, consistent, non-arbitrary enforcement is even more important than law-making. It involves access to justice, and it is expected and presumed to be equally fair. Deviating from this expectation would be a dramatic downfall in all legal systems, but even more in the EU, which is intended to be a supranational system founded on the rule of law.

\section{The rule of law as a conditional value in the EU: a proxy for a 'thin' rule of law concept}

Assuming that the EU does look at the rule of law in both its aspect of law-making and law enforcement, and, by doing so, it overcomes a division between legislations underpinned or not by EU law, what the EU requires of Member States to comply with in regard to the rule of law is another, complicated, matter.

${ }_{61}$ Jeff King, 'I-CONnet Symposium on "Constitutional Boundaries": The Social Dimension of the Rule of Law' (International Journal of Constitutional Law Blog, 27 April 2018) <www. iconnectblog.com/2018/04/i-connect-symposium-on-constitutional-boundaries-the-social-dimension-of-the-rule-of-law/> accessed 16 October 2019. 
A first elucidation in this area emerged, not surprisingly, during the Eastern Enlargement process, in the form of the Cooperation and Verification Mechanism (CVM) for Romania and Bulgaria. ${ }^{62}$ The mechanism was set up in consideration of the particular conditions of these two countries, which both showed worrisome conditions as regards the rule of law and which did not allow them to join the EU in 2004 together with the eight other post-communist countries. The CVM function consists of monitoring and reporting on whether these two countries comply with benchmarks in the areas of judicial reform, the fight against corruption and, specific to Bulgaria, the fight against organised crime. The CVM is therefore a tool that extended some of the EU's leverage over the rule of law from the pre-accession to the post-accession period. The mechanism empowers the Commission to take appropriate measures - including the suspension of the Member States' obligation to recognise and execute Bulgarian and Romanian judgments - in the case of an imminent risk that the countries would cause a breach in the functioning of the internal market by a failure to implement the commitments they had undertaken.

The CVM therefore represents a plausible framework for assessing what the rule of law is for the $\mathrm{EU}$, since compliance with this mechanism conditions access to the EU and remaining in the EU. There is no doubt that the rule of law is the main concern at the base of the CVM: in the premises, it reaffirms that the EU is based on the rule of law, that the EU space relies on the rule of law being assured and enforced in any Member States, and that this implies the existence of an impartial, independent and effective judicial and adequate administrative system. ${ }^{63}$

The following benchmarks, especially, have been considered for evaluating the existence of the rule of law in Romania (which will be taken as paradigmatic of both countries). First, a more transparent and efficient judicial process must be ensured, notably by enhancing the capacity and accountability of the Superior Council of Magistracy. Second, the impact

62 Commission, 'Decision of 13 December 2006 establishing a mechanism for cooperation and verification of progress in Romania to address specific benchmarks in the areas of judicial reform and the fight against corruption, notified under document number C(2006) 6570 final.

63 Milada Anna Vachudova, 'Why Improve EU Oversight of Rule of Law? The Two-Headed Problem of Defending Liberal Democracy and Fighting Corruption' in Closa and Kochenov (n 8) 270; Agnes Batory, 'Defying the Commission: Creative Compliance and Respect for the Rule of Law in the EU' (2016) 94(3) Public Administration 685; Ulrich Sedelmeier, 'Anchoring Democracy from Above? The European Union and Democratic Backslidings in Hungary and Romania after Accession' (2014) 52(1) Journal of Common Market Studies 105; Radu Carp, 'The Struggle for the Rule of Law in Romania as an EU Member State: The Role of the Cooperation and Verification Mechanism' (2014) 10(1) Utrecht Law Review 1; Mark Dawson and Elise Muir, 'Enforcing Fundamental Values: EU Law and Governance in Hungary and Romania' (2012) 19(4) Maastricht Journal of European \& Comparative Law 469. 
of the new civil and penal procedure codes must be reported and monitored. Third, an integrity agency must be established responsible for verifying assets, incompatibilities and potential conflicts of interest, and for issuing mandatory decisions on the basis of which dissuasive sanctions can be taken. Fourth, building on progress already made, professional, non-partisan investigations into allegations of high-level corruption must continue. Last, further measures must be taken to prevent and fight corruption, in particular at the local level.

The Commission clearly drafted these benchmarks with a 'thin' or a procedural conception of the rule of law: there is no mention of human rights, or any particular reference to human rights or to any substantial content to be guaranteed. What is required and expected is that the rule of law will be respected in the new Member State and that, as an ancillary provision, an efficient and impartial judiciary system will be established. There is no doubt that these rule of law elements have been picked up in consideration of the particular conditions of Bulgaria and Romania, which lacked the particular elements that the EU aimed to increase through its CVM. However, this does not mean that these elements are casual or just the outcome of circumstances. The fact that the EU wants to impose these thin or procedural elements means that these are precisely the ones that matter to the EU. This thin or procedural conception of the rule of law is not exclusively provided in the letter of the CVM, but it has also consistently applied in practice. Particularly, this happened during the Romania rule of law crisis of 2012. At that time, the Romania political landscape saw the confrontation of centre-left (Social Liberal Union, USL) and centre-right (Democrat Liberal Party, PDL) parties, also due to the institutional system of possible 'cohabitation'. During 2012, the USL Prime Minister, Viktor Ponta, tried to impeach the PDL party's Head of State, Traian Basescu, by adopting some emergency decree for easing its success, including firing the ombudsman ${ }^{64}$ and removing the presidents of the Chambers, ${ }^{65}$ specifically by lowering the threshold of the popular participation requirement needed for the referendum on impeachment. ${ }^{66}$

The Constitutional Court had indirectly declared this last decree unconstitutional, ${ }^{67}$ but the government decided that the referendum on impeachment could be carried out according to the invalid emergency ordinance. The whole scenario was aggravated by another emergency de-

\footnotetext{
64 Decision of Parliament 32, 30 July 2012; Constitutional Court 730, 9 July 2012.

65 Decision of the Senate 24, 3 July 2012; Decision of the Chamber of Deputies 25, 3 July 2012. See Constitutional Court of Romania, 9 July 2012, n 728.

66 Emergency Ordinance 41/2012, 5 July 2012.

67 Constitutional Court of Romania, 10 July 2012, n 731.
} 
cree through which the government removed from parliament the power of publishing law in the Official Journal, which gives it legitimacy. ${ }^{68}$ The EU took advantage of the upcoming deadline for issuing the Romania Report and pointed out, in the Report of 18 July 2012, that the recent steps of the Romanian government had called into question its commitment to the rule of law and explicitly requested that the Constitutional Court's ruling on the threshold of the referendum be respected. ${ }^{69}$ On 10-12 July 2012, Prime Minister Ponta went to Brussels to give explanations of the political development in the country to the presidents of the European Parliament, Commission and European Council. On that occasion, he received a list of requirements that the Romanian government was expected to comply with in regard to the respect of the rule of law. ${ }^{70}$

What the EU demanded was the enforcement of the rule of law as established in Romania, with a series of requirements regarding the law-making procedure, such as clarity, transparency and avoidance of conflicts of interest, but mostly the law as it was enforced, such as the independence of the judiciary and action against corruption.

The Report announced the prolongation of the CVM in the light of the Romanian government's steps, which had raised doubts about its commitment to the rule of law. ${ }^{71}$ In a letter of 16-17 July 2012, Prime Minister Ponta informed the Commission of his acceptance to carry out the recommendations: a joint session of the Romanian parliament on 1718 July 2012 amended emergency ordinance no 38/2012 on the reduced powers of the Constitutional Court and repealed the relevant provisions of emergency ordinance 41/2012. The popular participation requirement had been restored due to the publication, on 17 July 2012, of law $131 / 2012$ as amended by the Court. In conclusion, the EU managed the crisis successfully, using the CVM Report as leverage to bring Romania back into the realm of the rule of law before the crisis could further escalate. In its January 2013 Report, the Commission noted with satisfaction that most of its demands had been complied with. ${ }^{72}$

\footnotetext{
68 Emergency Ordinance 26/2012, 30 June 2012.

69 Commission, Press Release, 6 July 2012.

70 Repeal Emergency Ordinance no 38/2012 and Emergency Ordinance no 41/2012; Ensure that Constitutional Court rulings on the quorum for a referendum and the scope of the Court's responsibilities are respected; Respect constitutional requirements in issuing emergency ordinances in the future; Implement all Decisions of the Constitutional Court; Ensure the immediate publication of all Acts in the Official Journal, including the Decisions of the Constitutional Court; Require all political parties and government authorities to respect the independence of the judiciary. Commission, Press Release, 12 July 2012.

${ }_{71}$ Commission 2-3, 12 July 2012.

72 Commission, 'Report from the Commission to the European Parliament and the Council on progress in Romania under the cooperation and the verification mechanism COM(2013) 47 final.
} 
Even in the context of a visible crisis, these EU requests were mainly associated with thin and procedural conceptions of the rule of law. The EU's main concerns were that the rule of law, as established in Romania, was respected in the law-making, such as with regard to the conditions for issuing an emergency decree, and enforced in the law's enforcement, such as the quorum for presidential impeachment, the implementation of the Constitutional Court's decisions and their publication. The more substantial issues, such as the ban on issuing presidential pardons, the repeal of emergency decrees without conditions, or the enforcement of integrity rules in appointing ministers, still referred to a rule of law conception according to which the ruling of law should not be tainted by corruption, favouritism or abuse of power.

An outstanding example is provided with reference to the Report's analysis on parliamentary immunity: according to the Report, parliament's refusal to grant consent to investigate Members of Parliament generates de facto immunity from criminal investigation. It is not the law itself that is targeted, but its gross and corrupted enforcement. To this end, the Report mentions the case of several Members of Parliament where parliament's refusal to conduct inquiry could be equated with the impossibility of conducting criminal investigation. The Commission neither questions the mechanism of parliamentary immunity, as provided by the Constitution, nor the rule of the Romanian law, but rather discusses how these provisions are being applied where the enforcement of the law goes against the principle that the law should be obeyed.

In sum, the EU can admit that a Member State has its own rule of law in this specific area of criminal and constitutional law; it does not say that the national rule of law might be disregarded to the extent that the law no longer rules.

\section{Dismantling the issue of compliance as a rule of law conceptualisation problem}

One of the most critical points in the reconstruction of the EU attitude towards the rule of law, and particularly for crises related to it in the Member States, is the issue of compliance. This is because one of the most relevant rule of law crises, the one still happening in Hungary, has shown that the outcomes of EU intervention, despite the resort to binding tools, may not match aspirations.

As is known, Prime Minister Viktor Orban, leader of the national-populist party Fidesz, has steered the Hungarian constitutional landscape towards an autocratic regime through a skilful long-term strategy. Orban's strategy has consisted of systemically dismantling the checks and balances provided in the Constitution by repealing certain laws, 
enacting counter powers, and appointing officials loyal to him to the remaining control positions.

In April 2010, Fidesz obtained a two-thirds majority in parliament and proceeded to repeal the Constitution of 1949, heavily amended in 1989, replacing it with a new one. The whole legal framework was progressively dismantled and replaced by a new one, but always through legal means. ${ }^{73}$ In April 2011, the new Constitution was adopted. ${ }^{74}$ Before the end of the year, cardinal laws implementing the new system, which targeted the Constitutional Court followed by others that jeopardised academic freedom, ${ }^{75}$ the central bank, the data protection organ, and the judiciary. Specifically, by lowering the retirement age from 70 to 62 with immediate effect, the Hungarian government forced the departure of the most senior one tenth of the judiciary, including one quarter of the Supreme Court judges and one half of the Appeal Court presidents. The government then replaced these senior judges with judges of its own choosing, using a new legal procedure that put the choice of such judges into the hands of the president of a new institution, the National Judicial Office. ${ }^{76}$

The EU did not remain passive when confronted with these changes. While the issues regarding academic freedom and the independence of the central bank were resolved before the litigation phase, the Commission initiated an infringement procedure against Hungary with respect

\footnotetext{
73 Kim Lane Scheppele, 'Autocratic Legalism' (2018) University of Chicago Law Review 549; Pech and Scheppele (n 7) 3.

74 Actually, the whole process of constitution-making is suspected of being illegitimate, because it was in violation of the law then in force for constitution reform. According to Article 24(3) of the Constitution of 1989, as amended in 1995, the national parliament might amend the constitution with a two-thirds majority, while, according to Article 24(5), the national parliament might adopt a new constitution with a four-fifths majority. On 5 July 2010, the national parliament, pursuant to Article 24(3), repealed Article 24(5), then making it possible the following year to adopt a new constitution with a two-thirds majority, but by committing violations of the procedural rules in force at that time (Act XI of 1987 on Lawmaking, Article 40(1); Parliament Decision 46/1994 (IX 30) on the Rules of the Parliament of the Hungarian Republic, Article 85(3). See Petra Bárd, 'The Hungarian Fundamental Law and Related Constitutional Changes 2010-2013 (2013) 3 Revue des Affaires Européennes 457.

75 Commission, 'Hungary: Commission takes legal action on Higher Education Law and sets record straight on "Stop Brussels" consultation" Daily News MEX/17/1116, 26 April 2017. Subsequently, however, the restrictions on academic freedom were revived, particularly towards the Central European University and the Hungarian Academic of Sciences, imposing new requirements for establishment in Hungary against the former and putting the latter under ministerial supervision.

76 According to the Council of Europe, this reform amounted to a severe threat to the separation of powers. See Council of Europe Venice Commission, 15 October 2012, Opinion no $683 / 2012$.
} 
to the replacement of the Hungarian data protection commissioner, ${ }^{77}$ and the measures lowering the compulsory retirement age for judges. ${ }^{78}$

With regard to the judiciary case, the Commission used the Anti-Discrimination Directive ${ }^{79}$ as a legal ground for bringing Hungary before the CJEU. The Commission won the case - on the request of an expedite judgment - and Hungary complied with the ruling by amending the relevant law on the judiciary, ${ }^{80}$ setting new uniform retirement and allowing for the re-instatement of the unlawfully retired judges, unless their position had been filled in the meantime. For judges who did not ask for reinstatement, compensation was provided. In the case of data protection, the scheme was the same: the Commission invoked the violation of the Data Protection Directive and won the case. ${ }^{81}$ Hungary then gave compensation to the former commissioner and appointed a new one. Indeed, the legislation has been re-shaped in accordance with EU legislation, and the judges - and the data commissioner - who asked for reinstatement have been treated accordingly. However, there is the perception of a catch. The situation is even more complicated since both parties in the struggle, the Commission and the Hungarian government, claimed victory. ${ }^{82}$ In the judgment of 6 November 2012, the CJEU found that the compulsory retirement of judges settled by the Hungarian law infringed EU Directive 2000/78 because it gave rise to a difference in treatment on grounds of age that was not proportionate. ${ }^{83}$

Actually, the Hungarian Constitutional Court had already declared the judicial reform unconstitutional on 16 July $2012,{ }^{84}$ but this could not have impacted on Article 12 of the Transitional Provisions of the Fundamental Law, which formed the legal basis for enacting the reform and falls outside the scope of its jurisdiction. Thanks to the CJEU judgment, the Hungarian government could not circumvent the Constitutional Court ruling by simply over-constitutionalising its reform (for example,

\footnotetext{
77 Case C-288/12 Commission v Hungary ECLI:EU:C:2014:237.

78 Act XX of 2013 amending Act CLXII of 2011.

79 Council Directive 2000/78/EC of 27 November 2000 establishing a general framework for equal treatment in employment and occupation [2000] OJ L303/16.

80 Commission $v$ Hungary (n 77).

81 Directive 95/46/EC of the European Parliament and of the Council of 24 October 1995 on the protection of individuals with regard to the processing of personal data and on the free movement of such data [1995] OJ L281/31.

82 Dimitry Kochenov and Laurent Pech, 'Monitoring and Enforcement of the Rule of Law in the EU: Rhetoric and Reality' (2016) 5 University of Groningen, Law Faculty, Research Paper.

83 Mark Dawson and Elise Miur, 'Enforcing Fundamental Values: EU Law and Governance in Hungary and Romania' (2012) 19 Maastricht Journal of European and Comparative Law 471.

84 Constitutional Court of Hungary, Decision 33/12, VII/17.
} 
including it in the Fundamental Law) since the principle of supremacy would nonetheless have declared it to be against EU law. The EU intervention therefore added extra value that the national organs could not guarantee, since EU law, as the supreme law of the land, ${ }^{85}$ prevails also over constitutional law.

However, the limit of using the infringement procedure in this case consisted of its difficulty in grappling with a more extensive situation such as the Hungarian one. Admittedly, although many problems arose in connection with the constitutional changes, only a few of them led to the infringement procedure initiated by the Commission and, even in those cases, the claim referred to a limited set of deviations from EU law and did not engage the whole troubled situation of the rule of law. After all, the infringement procedure has been constructed to pursue non-compliance on a case-by-case basis and is ineffective in sanctioning a systemic threat.

Moreover, the EU realised that, even with rules and measures that openly defy pillars of the rule of law, such as judicial independence or the effectiveness of authorities' control, there is not much to be done when they do not fall within the scope of EU law action. Besides, the EU law scope of action is greatly limited here, since little EU legislation on these issues exists. Even when the Commission is able to find a legal basis such as the Anti-Discrimination Directive - there is bitterness not only vis-à-vis the ground itself, since it is clear that the underlying problem is the independence and not the discriminatory age, but also the full compliance with what the EU intended to be restored. Indeed, the failure to satisfactorily address the Hungarian situation perhaps remains the most critical point. ${ }^{86}$ The contested issue is that, as illustrated, during the infringement procedure against Hungary, the government waited until it had replaced most of the prematurely retired judges, before indicating that it would comply by allowing back any retired judges who wanted to come back. They could not, however, return to their former positions because those positions had already been filled, resulting in lower positions than before. Meanwhile, Hungary offered compensation

85 Case C-26/62 Van Gend \& Loos ECLI:EU:C:1963:1 and Case C-6/64 Costa $v$ Enel ECLI:EU:C:1964:66.

86 The case law clearly states that the sentenced Member State has to readdress its wrongdoings. The CJEU declared that the aim of the Treaty is to achieve the practical elimination of infringements and the consequences thereof, past and future (Case C-70/72 Commission $v$ Germany ECLI:EU:C:1973:87); in the case of infringement, Member States are obliged to rescind the measure in question and to make reparation for any unlawful consequences which may have ensued (Case C-6/60 Humblet $v$ Belgium ECLI:EU:C:1960:48). If compliance is not ensured, it is possible to resort to penalties. Indeed, it is plainly accepted that breaches to the rule of law have to be sanctioned in accordance with the EU rule of law landscape (Case C-340/02 Commission v France ECLI:EU:C:2004:623). 
to the prematurely retired judges if they did not want to go back to work, compensation accepted by most. ${ }^{87}$ Herein lies the most problematic issue for any rule of law system: unlawful consequences - such as the replacement of judges - should be set aside for not complying with the rule of law; but this is not always possible. ${ }^{88}$

However, there is no reason to believe that a 'thick' rule of law notion would have ensured a different outcome. It is not a matter of the theoretical qualification of the law infringed, or of the legal basis resorted to, but rather that compliance with the rule of law should be integral, whatever conception we adhere to. It is indeed naïve to think that a substantial concept of a theoretical legal concern automatically corresponds to the integral implementation of the same legal concept. What is typical of a legal system is its 'by and large' effectiveness. ${ }^{89} \mathrm{~A}$ legal system requires the existence of institutions that are generally capable of making and enforcing their decision for a collectivity in a certain territory. ${ }^{90}$ This capacity, resorting to coercion if necessary, is a classic identification of statehood, ${ }^{91}$ and relies on the idea of habit of compliance, by its actors. A good measure of the rule of law in a country is, for example, the extent to which public authorities obey the decisions, even uncomfortable ones, of their own courts. ${ }^{92}$ Nonetheless, all legal systems have a certain degree of non-compliance: they are legal systems yet, and so is the EU. In particular, the EU system shows an extraordinary compliance record by the standards of international law and appropriately comparable to national legal systems..$^{93}$ This is why it is possible to talk of an EU rule of law, while it is difficult to predicate the existence of an international rule of law. ${ }^{94}$

87 Gábor Halmai, 'The Early Retirement Age of the Hungarian Judges' in Fernanda Nicola and Bill Davies (eds), EU Law Stories: Contextual and Critical Histories of European Jurisprudence (CUP 2017) 471.

88 Undoubtedly, a claim to restore judicial independence would have led to a more comprehensive approach to the issue of the judicial early retirement than the discrimination grounds, but values, such as those in Article 2 TEU, are less tangible than clear obligations under EU law. Nonetheless, there is one value, that of the rule of law, which could always be applicable in its 'thin' version, in junction with the rule of EU law deriving obligations: and this value requires that compliance with the rule of law should be integral.

89 Hans Kelsen, General Theory of Law and State (Harvard University Press 1949) 120.

90 Thomas Risse, 'Governance in Areas of Limited Statehood: Introduction and Overview' in Thomas Risse (ed), Governance Without a State? (Columbia University Press 2014) 4.

91 Max Weber, Wirtschaft und Gesellschaft (Mohr 1972) 29.

92 Roland Bieber and Francesco Maiani, 'Enhancing Centralized Enforcement of EU Law: Pandora's Toolbox?' (2014) Common Market Law Review 1057.

93 Lisa Conant, 'Compliance and What EU Member States Make of It' in Marise Cremona (ed), Compliance and the Enforcement of EU Law (OUP 2012) 1.

94 Joseph HH Weiler, 'Epilogue: Living in a Glass House' in Closa and Kochenov (eds), Reinforcing Rule of Law Oversight in the European Union (CUP 2016) 324. 
The division 'thick' versus 'thin' rule of law does not coincide with the division 'full' or 'integral' versus 'formal' or 'cosmetic' compliance with the rule of law. ${ }^{95}$ The former distinction is about what the rule of law is composed of, the latter on whether this rule of law is respected, integrally or partially. Here again, the criticised inclination of the CJEU and the Commission to focus on the unlawfulness of national measures in the case against Hungary rather than on the ultimate failure to get results has nothing to do with the division of the 'thick' versus 'thin' conception of the rule of law. It is a matter of implementation of the content that could be most various. The need to set aside the unlawful measure and to implement the correct one is wholly compatible with a 'thin' rule of law conception; at the same time, the 'thick' conception could allow cosmetic compliance if the content is subsequently not enforced.

The integral implementation of what the law requires matches with both concepts of the rule of law. What is remarkable, however, is that, in the thin conception of the rule of law, integral implementation is due to the law's mere existence and not its particular content. ${ }^{96}$ Moreover, it commands this integral implementation because the law requires fidelity, and Member States have acceded to this relationship to EU law, as highlighted in Article 4(3) TFEU. From this perspective, 'integral' implementation is simply the last step in the rule of law's 'thin' concept implementation. The issue of compliance and the issue of conceptualisation remain therefore different. The EU institutions are not enforcing a thin rule of law concept as a downgrade of a 'thick' conceptualisation of the same. They are instead doing so because it is this concept of the rule of law that the Treaties prescribe and which animates the EU as a supranational entity. ${ }^{97}$

\section{Member State deficiencies in the rule of law: evaluation through a 'thin' rule of law concept}

The Poland rule of law crisis is probably the most relevant for defining the boundaries of the EU rule of law in consideration of the downfall of the rule of law - to such an extent as to doubt the existence of the rule of law in Poland ${ }^{98}$ - and for being the first case where Article 7 TEU was employed.

\footnotetext{
95 Jeremy Waldron, 'Rule by Law: A Much Maligned Preposition' (2015) Robin Cook Lecture 7.

96 Jeremy Waldron, Dignity of Legislation (CUP 1999) 15-16.

97 Jacques Ziller, 'National Constitutional Concepts in the New Constitution for Europe (2005) 1 European Constitutional Law Review 452.

98 Sadurski (n 60) 30; Dimitry Kochenov and Laurent Pech, 'Better Late Than Never? On the European Commission's Rule of Law Framework and Its First Activation' (2016) 54(5) Journal of Common Market Studies 1064.
} 
In Poland, the Law and Justice Party (PiS), led by Jaroslaw Kaczyns$\mathrm{ki}$, won the parliamentary election in October 2015. While the Law and Justice Party may have a similar ideological background to Fidesz and aims to emulate it, it lacked the overwhelming majority the latter enjoyed in the national parliament. ${ }^{99}$ Therefore, in order to reshape the constitutional order, the Poland government mainly acted simply by disregarding the legal framework. The president of the Republic, from the Law and Justice Party, refused to swear in the new members of the Constitutional Court, nominated by the former parliament, ${ }^{100}$ replacing them with five other judges appointed by the newly elected parliament. ${ }^{101}$ Consequently, the Constitutional Court could no longer perform its duties in its due composition. The refusal of the president to swear in the elected judges violated the Constitution that does not give the president any such role in deciding about the composition of the Constitutional Court.

Another clash between the powers happened when the government refused to publish Constitutional Court decisions, thereby making them ineffective, since the binding value of the decisions is linked to their publication. ${ }^{102}$ Here, too, there was a flagrant violation of the law, since the government broke Article 190(2) of the Constitution of Poland, which demands that the government publishes judgments immediately, and which does not give it any power to control the judgments submitted

99 Wojciech Sadurski, Poland Constitutional Breakdown (OUP 2019) 3.

100 On 8 October 2015, parliament elected five new judges, rather than only three, to positions that became vacant during the parliamentary term. Electing those two extra judges was clearly improper, as subsequently stated by the Constitutional Court (3 December 2015, K34/15), but electing the three judges was correct, because the vacancies fell on 6 November, while the first day of the new term of the new parliament was 12 November. The new parliament adopted a Resolution on 25 November 2015, according to which all five, including the 3 correctly elected, were elected irregularly, and so the elections of all five were null and void. On that basis, on 2 December 2015, it elected five new judges. The situation became even more dramatic when the Constitutional Court, now also composed of the unlawfully elected judges, struck down judgment K34/15 by reinterpreting it - mainly assessing that the constitutive moment of the appointment relies on the swearing-in by the president - and then legitimising the unlawfully elected judges (24 October 2017, K1/17). Finally, the three lawfully elected judges were removed from judging for an indefinite period of time (Minister of Justice Motion of 11 January 2017). Thus, the government not only dismantled the Constitutional Court's control, but it turned it into an active aide in its strategy. See Sadurski (n 60) 31-33.

101 Constitutional Court, 5 December 2015, K35/15, which declared unconstitutional the law of 19 November 2015, according to which the three extra judges had been elected by the new parliament.

102 Particularly after the judgment of 9 March 2016, K47/15, which struck down the newly adopted constraints to the Constitutional Court's scope, composition and activity enacted by the law of 22 December 2015, the government deliberated that all Constitutional Court judgments delivered in violation of that law could not be published in the Official Gazette. As Sadurski notes, the government refused to publish the judgments handed down in violation of a statute, which was invalidated in the very judgment that the government refused to publish. Over time, the judgments were published, except for the judgment of 9 March 2016, K47/15. See Sadurski (n 60) 29. 
for publication. In addition to these clear violations of the law, the government also adopted new legislation, formally within its competences, regarding the Constitutional Court's composition ${ }^{103}$ and function, the appointment of the National Council of the Judiciary, the organisation of ordinary courts, and the retirement age for Supreme Court judges, all in order to restrain the judicial controls over the government. ${ }^{104}$

Before activating Article 7 TEU, following dialogue with the authorities of Poland that started on 13 January 2016, the Commission adopted a Rule of Law Opinion on 1 June 2016, under the newly adopted Rule of Law Framework. The Rule of Law Opinion identified the matters of relevance as mainly the lack of implementation of the judgments of the Polish Constitutional Tribunal of 3 and 9 December 2015, and the failure to publish and implement the judgment of 9 March 2016. Shortly afterwards, on 27 July 2016, the Commission adopted Recommendation 2016/1374 regarding the rule of law in Poland. ${ }^{105}$ The Recommendation explained the circumstances and the grounds on which the Rule of Law Opinion had been made and the steps to follow. In compliance with the Rule of Law Framework, after the adoption of the Rule of Law Opinion and Recommendations 2016/1374, the Commission adopted two other Recommendations, 2016/146 ${ }^{106}$ and 2017/1250. ${ }^{107}$

Particularly in the third Recommendation, the Commission clearly stated that, should the authorities of Poland hold their course, the Commission stood ready to activate Article 7(1) TEU. In the meantime, the Poland government kept on enacting laws to restrain judiciary control ${ }^{108}$

\footnotetext{
103 The series of law provisions which were adopted for preventing the work of the Constitutional Court may be divided into three groups: provisions which exempt new laws from constitutional control or which delay them (eg Art 1(12)(a) of the law of 22 December 2015); provisions which paralyse a Constitutional Court's judicial decision (eg Art 1(3) of the law of 22 December 2015); provisions which reinforce the government's control over the Constitutional Court (Art 1(5) of the law of 22 December 2015).

104 Act of 22-28 December 2015. Act of 15-18 December 2017. Act of 24-26 July 2017. Act of 8-15 December 2017.

105 Commission, 'Recommendation 2016/1374 of 27 July 2016 regarding the rule of law in Poland' [2016] OJ L217/53.

106 Commission, 'Recommendation 2016/146 of 21 December 2016 regarding the rule of law in Poland complementary to Recommendation 2016/1374' [2017] OJ L22/65.

107 Commission, 'Recommendation 2017/1520 of 26 July 2017 regarding the rule of law in Poland complementary to Recommendations 2016/1374 and 2017/146' [2017] OJ L228/19.

108 The Commission observes that, within a period of two years, more than 13 consecutive laws have been adopted, affecting the entire structure of the justice system in Poland: the Constitutional Tribunal, the Supreme Court, the ordinary courts, the National Council for the Judiciary, the prosecution service and the National School of Judiciary. The common pattern of these legislative changes is that the government has been systemically enabled to interfere significantly with the composition, the powers, the administration, and the functioning of these authorities and bodies. The legislative changes and their combined effects put the independence of the judiciary and the separation of powers, which are key compo-
} 
and the now controlled Constitutional Court. The constitutionality of the statutes that were adopted by the government was declared in panels, including the unlawfully elected judges. ${ }^{109}$

On 20 December 2017, the Commission at last adopted a reasoned proposal on the determination of a clear risk of a serious breach of the rule of law by Poland, invoking Article 7(1) TEU for the first time since its inception. ${ }^{110}$ The Commission recommended Poland to take the following actions within three months after notification of this Decision: restore the independence and legitimacy of the Constitutional Tribunal as guarantor of the Polish Constitution by ensuring that its judges, its president and its vice-president are lawfully elected and appointed; by fully implementing the judgments of the Constitutional Tribunal of 3 and 9 December 2015, which required that the three judges that were lawfully nominated in October 2015 by the previous legislature take up their function of judge in the Constitutional Tribunal, and that the three judges nominated by the new legislature without a valid legal basis no longer adjudicate without being validly elected; and publish and fully implement the judgments of the Constitutional Tribunal of 9 March 2016, 11 August 2016 and 7 November 2016. ${ }^{111}$ The Commission's concerns regard the adoption of new legislation on the judiciary by Poland, which undermined judicial independence. This especially involved, on the one hand, the series of acts which interfered with the Constitutional Court's activity and composition, and, on the other hand, the law on the Supreme Court of December 15, 2017; the law on the Organisation of Ordinary Courts of 28 July 2017; the law on the National Council for the Judiciary of 15 December 2017; and the law on the National School of the Judiciary of 13 June 2017.112

nents of the rule of law, at serious risk in Poland. Commission, 'Reasoned proposal of 20 December 2017 in accordance with article 7(1) of the Treaty on European Union regarding the rule of law in Poland, Brussels COM(2017) 835 final para 173.

109 The unlawful appointment of the president of the Constitutional Tribunal, the admission of the three judges nominated by the Sejm without a valid legal basis, the fact that one of these judges has been appointed as vice-president of the Tribunal, the fact that the three judges that were lawfully nominated in October 2015 by the previous legislature have not been able to take up their function of judge in the Tribunal, as well as the subsequent developments within the Tribunal described above de facto led to a complete restructuration of the Tribunal outside the normal constitutional process for the appointment of judges. For this reason, the Commission considered that the independence and legitimacy of the Constitutional Tribunal were seriously undermined and, consequently, the constitutionality of Polish laws could no longer be effectively guaranteed. The judgments rendered by the Tribunal under these circumstances could no longer be considered as providing an effective constitutional review. Commission, 'Reasoned proposal' (n 108) para 57.

110 ibid.

111 ibid, para 42, (a); (b).

112 ibid, para 42 , (c). 
First and foremost, the EU initiative against Poland has a clear foundation: the EU rule of law also contains the rule of national law; in this case, Polish law. The Commission was particularly worried about the fact that binding rulings of the Constitutional Tribunal were not respected, which is a serious matter in any rule-of-law- state. ${ }^{113}$ The other criticisms, such as on the actions that undermine the legitimacy of the judiciary, were side issues: the most important issue repeated everywhere as the main concern is that states must obey the law as established by their own rule of law. Indeed, in all three Recommendations, as well as in the reasoned proposal (para 93), the Commission states that the judges elected according to the law should be reinstated, while those unlawfully elected should no longer be part of the Constitutional Court. Simply put, it has to apply the national law as it is provided, and to undo the government's partisan choice against the rule of law. In the same way, the Commission states that the judgments of the Constitutional Court are unconditionally binding and as such must be published (para 98); the refusal of the government to publish them is a serious concern in respect of the rule of law, as compliance with final judgments is an essential requirement inherent in the rule of law, while any control over them by a state authority is incompatible with it (para100). ${ }^{114}$

Thus, there is no reference to any EU law provision, but rather to the general rule of law ideal itself, which the Commission takes upon itself to control. And the message of the rule of law is to obey the law as it is, sanctioning its violation or circumvention. Furthermore, as highlighted in the second recommendation, the appointment of the president of the Constitutional Court represented a serious rule of law issue (para 104). This appointment was led by an acting president whose designation was in violation of the principles of the separation of powers and the independence of the judiciary, which constitute pillars of any rule of law conception. The following actions regarding the Constitutional Court's composition and functions are all based on a violation of these principles that made the Constitutional Court in Poland irregular and a danger to the rule of law itself, rather than one of its guardians (paras105 and109). The other concerns (para 115 and following) regard other troublesome issues in the rule of law, but carried out through legal means, which amount to rule of law violations according to their systematicity and cumulative effects. The Commission highlights that these rule of law violations through laws systemically represent a threat to the rule of law. That is to

\footnotetext{
113 Readout by First Vice-President Timmermans of the College Meeting of 13 January 2016.

114 Tomasz T Koncewicz, 'The Capture of the Polish Constitutional Tribunal and Beyond: Of Institution(s), Fidelities and the Rule of Law in Flux' (2018) 43 Review of Central and East European Law 122.
} 
say, taken separately, they are only a matter of suspicion, whereas only their combined effect represents a violation, differently from the other government actions which were per se against to the rule of law, in its pillar of obey the law and separation of powers (para 175). These seem to be side issues in respect of the more flagrant rule of law violation of acting with clear disregard for the existing law and annihilating the rule of law principles. It should therefore come as no surprise that the Commission is of the opinion that the situation in Poland represents a clear risk of a serious breach of the rule of law, as described in Article 2 TEU (para 172). Moreover, as pointed out later (para 180(3)), respect of the rule of law is not only a prerequisite for the protection of all the fundamental values listed in Article $2 \mathrm{TEU}$, it is also a prerequisite for upholding all rights deriving from the Treaties and for establishing mutual trust between citizens, corporations and national authorities in the legal system of all Member States, also with regard to the internal market, justice, home affairs and judicial cooperation (para 180(3)).

The rule of law emerges as the main EU concern and the main value among the many of Article 2 TEU: because it is a value per se (being part of Article 2 TEU); because it protects the other values of Article 2 TEU; lastly, because it characterises the EU legal order, being the raison d'être of the EU as an international organisation sui generis. It appears that rule of law systems are not threatened by individual or isolated infringements. ${ }^{115}$ The Article 7 TEU procedure is reserved for those 'systemic' cases, which are likely to systemically and adversely affect the integrity, stability or proper functioning of the institutions at a national level to secure the rule of law. The EU Commission observes what does not function in Member States from an institutional point of view, in ensuring that the rule of law is enforced. EU actions principally refer to the central position of the Constitutional Tribunal within the Polish judicial system, the situation of which is at risk of leading to the emergence of a systemic threat to the rule of law. To reach this serious conclusion, the Commission has monitored Poland for more than two years, registering at least 13 consecutive laws or initiatives that, in their combined effects, have led to this situation (para 173): the common pattern of all these actions is that there has been a systematic decrease in the rule of law by the government. It seems reasonable to ask why, confronted with the blatant violations of the rule of law in the Polish case, the employment of Article 7 TEU has taken so long.

There have been good reasons for the general reticence to use Article 7 TEU. First, it is a blunt instrument (even in the preventive version in

115 Commission, 'Communication from the Commission of 11 March 2014: A new EU Framework to strengthen the Rule of Law [2014] COM(2014) 158 final, para 6. 
Article 7(1) TEU) in a community more based on integration than sanctioning. Voting against a fellow Member State (and votes by other Member States in the Council) is politically costly and may easily be portrayed as hostility towards the nation itself, rather than vis-à-vis the government of the state concerned. As a matter of fact, it is a political instrument in a community deeply legalised, where legal remedies are more privileged than political ones.

As pointed out by the Commission (para 182), Member States are free to organise their justice system, including establishing or not a Council of the Judiciary and the degree of the constitutional courts' review. However, the purpose they serve, such as the independence of the judiciary, the separation of powers, should be commensurate with the EU standards of the rule of law. This is why the laws adopted do not represent a danger per se: they represent a danger when they blatantly undermine the purpose they serve, such as when the law is simply disregarded, or through a cumulative effect, such as by consecutive laws that dismantle the judiciary. Thus, the request of the Commission to the Council is to declare the clear risk of a serious breach of the rule of law and for Poland to implement the judgment of 3 and 9 December 2015, and to publish and implement those of 9 March 2016, 11 August 2016, and 7 November 2016, since the Polish actions have simply defied this request. With regard to the various laws on the judiciary, which only cumulatively and systemically represent a breach of the rule of law, the request is to amend them in order to ensure the purpose of the independent judicial system. That is to say, Member States are indeed free to regulate judicial activity and functions, yet the law is to be obeyed and the law should provide a certain procedural guarantee in a rule of law system. ${ }^{116}$

116 The EU Parliament has expressed a different opinion on this matter. Bemoaning that the Commission did not respond to its call to activate its EU Framework to strengthen the rule of law, the European Parliament Resolution of 17 May 2017, on the situation in Hungary (2017/2656(RSP), § 8. Parliament acted independently, affirming that the Commission's approach failed to lead to real changes and voted for the application of Article 7 TEU against Hungary (European Parliament Resolution of 12 September 2018, on a proposal calling on the Council to determine, pursuant to Article 7(1) of the Treaty on European Union, the existence of a clear risk of a serious breach by Hungary of the values on which the Union is founded (2017/2131(INL). The Parliament's Resolution links 'thin' rule of law concerns, regarding the independence of the judiciary, to more 'thick' rule of law concerns, such as those regarding migrants' rights, which the Commission tackled with the infringement procedures, for which there are still cases pending before the ECJ (paras 70, 71). Beyond this, many concerns described in the proposal do not amount to systemic rule of law violations, lacking actual and concrete government action (paras 11,51,58), and insisting on singular rights denials. It is not the case that the main source of information is the ECtHR case law (paras 16, 25, 29, 55), which deals with individual complaints and only indirectly with rule of law matters. Lastly, the progress made by Hungary in many areas (paras 13, 19, 29, 48), its continuous dialogue with the EU (paras 4, 18) - Hungary asked to be, and has been, heard according to Article 7(1) TEU - and the lack of Recommendations as provided by the Rule of Law Framework, makes the Hungarian situation a grey area still. Interestingly, in- 


\section{The institutional reasons for a 'thin' rule of law concept in the EU}

This analysis has sketched a landscape of unlawful practices that the EU condemns and tries to arrest, in different ways and with different outcomes, as well as a precise standard to be maintained of the 'thin' rule of law.

And, beyond what has been done in practice, there are sound institutional reasons for having a 'thin' rule of law conception governing the EU. ${ }^{117}$ At first glance, the concept of the rule of law in the EU could seem a 'thick' or substantial one, wherein the rule of law is informed by material content and, particularly, by democracy and human rights. ${ }^{118}$ Actually, it was this conception of the rule of law that emerged from World War II as a binding agent and common perspective among the founding Member States. ${ }^{119}$ Furthermore, for the newest EU Members States, it was one of the pillars of the constitutional and political transformation they undertook. ${ }^{120}$ According to this conception, the rule of law in the EU would be meaningless if separated from democracy and human rights. ${ }^{121}$ A 'thin' or formal conception of the rule of law, ${ }^{122}$ by contrast, would include everything and exclude nothing. ${ }^{123}$ On the one hand, it would be another name for modernity, or for societies ruled by the law, which is the most common situation in most states and, therefore, it would have no informative value. On the other hand, the best outcome would simply be an account of the rule by law, which is the situations of authoritarian regimes that the EU aims to fight.

deed, the EU Parliament titled the proposal 'breach of the EU values' instead of 'breach of the Rule of Law' as the Commission did in the case of Poland.

117 Dimitry Kochenov, Gráinne De Búrca and Andrew Williams (eds), Europe's Justice Deficit (Hart Publishing 2015); Peter L Lindseth, Power and Legitimacy: Reconciling Europe and the Nation State (OUP 2010); Brian Tamanaha, On the Rule of Law: History, Politics, Theory (CUP 2004); Tom Bingham, The Rule of Law (Penguin Books 2010); Maria Luisa Fernandez Esteban, The Rule of Law in the European Constitution (Kluwer Law International 1999); Joseph HH Weiler, The Constitution of Europe (CUP 1999).

118 Ronald Dworkin, Law's Empire (Harvard University Press 1986) 15-20.

119 Joseph HH Weiler, 'Epilogue: Living in a Glass House' in Carlos Closa and Dimitry Kochenov (eds), Reinforcing Rule of Law Oversight in the European Union (CUP 2016) 315-317.

120 Sadurski (n 19) 2.

${ }^{121}$ And this 'thick' conceptualisation of the EU rule of law can still be true in its external relationship from both a descriptive point of view (since it is one of the chapters of negotiations) and a normative one, since it has an appealing value that is different from what the Member States stand for once in the political community, differently from the applicant states. I owe this remark to Matteo Bonelli.

122 John Ralws, A Theory of Justice (Harvard University Press 1999) 206-213; Joseph Raz, The Authority of Law: Essays on Law and Morality (Clarendon Press 1979) 195; Lon L Fuller, The Morality of Law (Yale University Press 1964) 33.

123 Juri Pribàn, 'From "Which Rule of Law?" to "The Rule of Which Law?": Post-Communist Experiences of European Legal Integration' (2009) 1 Hague Journal on the Rule of Law 338. 
This theory, despite having considerable support, does not respect certain rule of law values and needs. Before entering into further detail, however, a misunderstanding should be cleared up. Sustaining the opinion that the rule of law is separate from human rights and democracy does not mean that all these values have nothing in common, nor does it mean at all that the EU does not care about them. It simply means that the rule of law, human rights and democracy are separate items: close enough to be part of the same constellation, but still different stars. ${ }^{124}$ Together, they compose a political constellation that represents the common features of the Member States and the EU itself to different degrees. Indeed, Article 2 TEU provides democracy, human rights and rule of law, meaning that they relate to each other but as separate and independent concepts. ${ }^{125}$ The fact that they share common features and coordinate action for the same purpose does not mean that they are the same thing, as much as, for the sake of constitutionalism, having checks and balances or free and democratic elections contributes to the same object but are not the same thing. Nothing is achieved and much is lost by simply listing the rule of law, human rights and democracy as though they have the same rationale: clarity in practice and effectiveness of the theory are achieved by recognising their diversity. ${ }^{126}$

Historical circumstances bear this out as well. ${ }^{127}$ The time for the conception of the rule of law that merges human rights and democracy together has passed within the EU project. A 'thick' conception of the rule of law may have had value in the time of division, when the EU was an appealing community of values for countries with an authoritarian past, first Fascist and Nazi, then military leaderships, and lastly Communist. Nowadays, the EU expresses a slightly different ideal. Particularly, the statement of being a space of liberty and justice means that its community of values has two dimensions: a political-legal dimension, centred on human rights, to which even democracy should submit, and a legal-political dimension, built upon the rule of law, where consistency with the rule of law, without inquiry into the type of law, represents its first and foremost condition. From among the two, the EU derives its appeal from the latter dimension rather than from the former. Indeed,

\footnotetext{
124 Jeremy Waldron, The Rule of Law in Public Law (Cambridge Public Companion 2014) 11.

125 Werner Schroeder, The European Union and the Rule of Law: State of Affairs and Ways of Strengthening' in Schroeder (n 54) 32.

$126 \operatorname{Raz}(n$ 56) 11.

127 Also considering that, from a historical standpoint, it is difficult to sustain that many modern rule of law states, fatherlands of the concept, which did not have this or that human rights, were not a rule of law system: the rule of law has been strong and alive in non-democratic and in non-human rights societies. Joseph Raz, The Authority of Law: Essays on Law and Morality (Clarendon Press 1979) 211.
} 
its legitimacy springs neither from being a human rights actor, nor from being a continent-wide democracy: rather, it claims legitimacy because the Member States have freely voted to bind themselves to and follow a rule of law system, at the top of which lies EU law. Here, the principles of supremacy and direct effect are the foundational values of the EU rule of law system. ${ }^{128}$ Moreover, they are both immediately linked with a rule of law concept that is not mandatorily embedded with human rights or any other substantial content.

As a last preliminary remark, it also seems important to stress that the fight for the rule of law should not be captured by inherent politicisation which characterises fields such as human rights and democracy: nothing is to be gained from this approach for the rule of law, the other values at stake, or the EU and its Member States. Democracy means uncertainty - nobody can know or should know the outcome of an election in advance - while the rule of law means certainty for the sake of the legal stability and effectiveness of its command. ${ }^{129}$ Human rights instead require certainty in terms of substantial contents and structures more than the rule of law, which requires openness to changing lawmakers' political will. ${ }^{130}$ On this account, in European integration, the rule of law was not included - and could not have been included - in the summa divisio which, in the early days of the EU, assigned the establishment of the common market to the European Union and the protection of human rights to the Council of Europe. ${ }^{131}$ Both of these were political tasks, as was the establishment of an EU constitutional structure, which were also parts of the process at the root of the EU enlargement. Rule of law is a different matter: one of maturity of the legal system, not of political bargaining. The EU is laboriously reaching this threshold.

\footnotetext{
${ }_{128}$ Dimitry Kochenov, 'The EU and the Rule of Law: Naiveté or Grand Design?' in András Jakab and Dimitry Kochenov (eds), The Enforcement of EU Law and Values. Ensuring Member States' Compliance (OUP 2017) 428; Francis Jacobs, The Sovereignty of Law: The European Way (CUP 2007) 40; Karen Alter, Establishing the Supremacy of European Law: The Making of an International Rule of Law in Europe (OUP 2003) 28.

129 Jan Werner Muller, 'The EU as a Militant Democracy, or: Are There Limits to Constitutional Mutations within EU Member States?' (2014) Revista de Estudios Político 157.

130 Most of the Art 2 TEU values, like dignity, freedom, equality between women and men, freedom and non-discrimination, can be held as more specific expressions of human rights and, not surprisingly, they all have equivalents in the EU Charter of Fundamental Rights: human dignity in Title I, freedom in Title II, equality between women and men in Title III, and so on; only two values, rule of law and democracy, cannot be directly operationalised as human rights. See Gabriel Toggenburg and Jonas Grimheden, 'Managing the Rule of Law in a Heterogeneous Context: A Fundamental Rights Perspective on Ways Forward' in Schroeder, Strengthening the Rule of Law in Europe (n 54) 227.

131 Gráinne De Búrca, 'Beyond the Charter: How Enlargement has Enlarged the Human Rights Policy of the European Union' (2004) 27 Fordham International Law Journal 683.
} 
However, there is a more substantial kind of criticism of an allegedly 'thick' conception in the EU's rule of law system. Firstly, if, from an historical standpoint, the 'thin' rule of law conception could have facilitated totalitarian regime abuses, ${ }^{132}$ from a logical point of view, the 'thick' rule of law conception is super inclusive, giving no legal explanation of different phenomena and adding no informative value. This 'thick' rule of law criticism of the 'thin' one is mostly of a political nature, and it has also an inevitable tendency of a reductio ad Hitlerum. Indeed, the legal theory view of the law as a moral project, according to which a law grossly violating the principle of justice is a lawless law, could be sustained even without resorting to the 'thick' rule of law conception. ${ }^{133}$ Injustice in the rule of law is not caused when the rule of law does not contain this or that human right, but when the law is framed utterly unjustly, with regard to its requirements, here referring to a 'thin' or 'procedural' rule of law conception, and when the law is enforced unjustly, against the very sense of the law.

Secondly, once we open up the possibility of fleshing out the rule of law with substantial content, and not just formal and procedural requirements, a competition among possible substantial values would suddenly take place. Should dignity or freedom be the main substantial component of the rule of law in the EU? Or perhaps the market economy and property rights or social justice, or any other values listed in the EU Charter? The result will be a general decline in the articulation and framing of the rule of law, as people - or, as it happens, Member States will struggle to use the same term to express different ideals or different terms to express the same ideal. ${ }^{134}$

A third point in favour of a 'thin' conception of the rule of law in the $\mathrm{EU}$ relies on the fact that it alone provides fidelity to the law that the EU needs as a functioning mechanism of its rule of law system. A 'thick' conception of the rule of law will always be ideologically and politically compromised, and thereby precarious. Fidelity to a 'thin' rule of law, by contrast, is predicated on what the law is, and not just what it is used for (enforcing this or that right or policy), thus independent of any instrumental conception of the law. The rule of law has a peculiar dimension of allegiance that is expected to sustain itself, even when disagreement exists on the goal to be achieved. ${ }^{135}$ This is exactly the legal landscape

\footnotetext{
132 Even though the identification 'thin' rule of law - totalitarian regimes is recognised as fallacious. Waldron (n 95) 14.

133 Neil MacCormick, Rhetoric and the Rule of Law: A Theory of Legal Reasoning (OUP 2010). 134 Jeremy Waldron, 'The Rule of Law and the Measure of Property' (2011) The Hamlyn Lectures 27.

135 Lon L Fuller, 'Positivism and Fidelity to Law: A Reply to Professor Hart' (1958) 71 Harvard Law Review 630-632.
} 
that has sustained the development of the EU and EU law. In the 'thin' conception of the rule of law, there is a source of autonomous respect inherent in legality, which sustains this fidelity as such, not depending on the substantive aim the law is pursuing. Accordingly, the formal law requirements provide the link between legality and fidelity. ${ }^{136}$

Laws which satisfy those requirements have, for that reason, a claim to allegiance, independently of their substantive ends. As Dworkin highlights, we prove repugnance and we lose fidelity to the law by 'checkerboard' statutes, such as, for example, a statute making abortion illegal for women born in even years but not for those born in odd years, regardless of what we think about the substantial issue - abortion - at stake. ${ }^{137} \mathrm{We}$ expect the law to be in compliance with law's formal requirements, even if we may disagree about what it should provide. Herein lies the first core principle of the rule of law: the law should have certain requirements to be such. These requirements may vary, but they all identify a series of elements that are held to be essential to the law: generality, publicity, consistency, and so on. ${ }^{138}$ The EU Parliament's alarm about the Berlusconi government's irregularity was precisely founded on this conception that the law, to be such, must be general, irrespective of how debatable its content can be. Saving the prime minister from criminal prosecution or reducing the statute of limitations could be acceptable under the EU rule of law there is a great variety in Member States' legislation in this area: what is incompatible with the rule of law requirement of generality is the coincidence between the lawmaker and the only possible beneficiary of the law.

However, having laws that respect certain requirements does not exhaust the rule of law values, even in its 'thin' version. It is possible to imagine a scenario where all the formal requirements of the rule of law are present, but still the law does not rule at all. Following the previous example, concerning a law that provides that abortion is illegal (or legal) for everyone, it would not be acceptable for the law itself to be disregarded, in the law's enforcement, by making abortion exclusively legal (or illegal) for a specific someone. Fidelity to the law relies on the fact that the law as such is the object of allegiance, irrespective of its content. Even if a departure from the law would actually help to achieve the goal of the law itself, the principle of the rule of law prevents this. In other words, the state's demands for pursuing the goal will never be made differently from the provided legal background. The appeal to fidelity is not made

\footnotetext{
136 Jeremy Waldron, 'Why Law - Efficacy, Freedom, or Fidelity?' (1994) 13 Law and Philosophy 275.

137 Ronald Dworkin, Law's Empire (Harvard University Press 1986) 166.

138 Lon L Fuller, The Morality of Law (Yale University Press 1964) 33; Joseph Raz, The Authority of Law: Essays on Law and Morality (Clarendon Press 1979) 210.
} 
on the grounds of any substantial content; it is made on the ground of bond reciprocity. ${ }^{139}$ There is reciprocity between rulers and the ruled with respect to the observance of rules: ${ }^{140}$ when the bond of reciprocity is broken, there is no reason why the law should be observed. ${ }^{141}$

Thus, considering that the law should rule, the law should rule alone. ${ }^{142}$ In order for the law to rule, the law should apply to all actors in the legal order. A shared, diffuse, prevailing habit of obedience to the law by everyone is a central concern in this matter. This forms the second core principle of the rule of law: the law requires obedience not because it is the law (which would be tautology), ${ }^{143}$ but because this obedience to the law and the law itself are parts of the rule of law system. ${ }^{144}$ This principle is clearly described in the eighth requirement of Fuller's list regarding the congruence between rule and official action, ${ }^{145}$ or in Rawls' deontological requirement to take the law seriously. ${ }^{146}$ Whether or not it is declared in national constitutions or EU Treaties, the law always presupposes obedience, ${ }^{147}$ and consequently so does EU law.

This characterises the EU rule of law system in all its relations of governance: between the EU and its citizens, between Member States and their citizens, and between the EU and its Member States. ${ }^{148}$ Actually, the CJEU lists some principles in its case law, which can lead back

\footnotetext{
139 Waldron (n 134) 280.

140 David Haljan, 'Is the Rule of Law a Limit on Popular Sovereignty' in Erik Claes (ed), Facing the Limits of the Law (Spenger 2009) 278.

${ }_{141}$ This principle applies to the whole package of formal requirements of the law: ad personam, unintelligible, retroactive, unstable laws have few grounds on which to stimulate citizens' loyalty in terms of a duty to obey the rules. Still, it is possible to enact such laws and pretend obedience to the claim for allegiance passed through parameters that are universal in abstracto and applicable to anyone who meets certain conditions in concreto. Deviations from the formal requirements are sometimes needed: the rule of law can bear them and inspire allegiance as long as the law's enforcement is not the result of the present concrete situation, but the consequence of the abstract meaning of the law, as required by the congruity principle. Interestingly, Fuller describes this principle as the most 'procedural', meaning its importance in the law's enforcement: formal-procedural requirements work in close synergy, as a law may be formally good, yet abused and/or rendered useless at the enforcement level.

142 Martin Krygier, 'Rule of Law' in Michel Rosenfeld and Andràs Sajo (eds), The Oxford Handbook of Comparative Constitutional Law (OUP 2012) 212; Franz Merli, 'Principle of Legality and the Hierarchy of Norms' in Schroeder (n 54) 38.

143 Jeremy Waldron, 'Legislation and the Rule of Law' (2007) 1(1) Legisprudence 97.

144 Kalypso Nicolaidis and Rachel Kleinfield, 'Rethinking Europe's Rule of Law and Enlargement Agenda', Sigma Paper 49, 8.

145 Lon L Fuller, The Morality of Law (Yale University Press 1965) 39-40.

146 John Rawls, A Theory of Justice, (OUP 1996) 206-213.

147 Jeremy Waldron, 'Public Rule of Law' (2014) Keynote Address at ICONS Firenze, 19.

148 Daniel Francis, 'From Utopia to Apology: The European Union and the Challenge of Liberal Supranationalism' (2017) Classical Liberal Institute NYU 5.
} 
to these two rule of law requirements. The principle of legal certainty requires that rules of law be clear and precise and predictable in their effect, so that interested parties can ascertain their position in situations and legal relationships governed by EU law. ${ }^{149}$ The principle of legal certainty goes hand in hand with that of the legitimate expectations for which the laws have to be clear, predictable and prospective. In this regard, the CJEU recognises the prohibition of retroactivity, but limited to the criminal law area (otherwise applying the legislation in force). ${ }^{150}$ The CJEU recognises that the rule of law is twofold, or that the same principle has two implications: the presence of the rule of law on the one hand means that any public intervention must have a legal basis and be justified on the grounds laid down in the law, and that, on the other hand, its action is effective. ${ }^{151}$

In other words, the ruling should be lawful and the law should rule, as also recently clearly expressed with regard to the Hungary case. ${ }^{152}$ In addition, the EU legal system as a rule of law system includes the right to challenge the validity of regulations by legal action. That principle also imposes upon all persons subject to EU law the obligation to acknowledge that regulations are fully effective as long as they have not been declared invalid by a competent court. ${ }^{153}$ Its binding nature is a particular requisite of the law and its proper enforcement. ${ }^{154}$ The CJEU has recently reiterated that the effective application of EU law is an essential component of the rule of law principle as envisaged in Article 2 TEU $^{155}$ and that adherence to legality must be properly ensured. ${ }^{156}$ The CJEU clearly affirms that the law, whatever its content, must be effective, or that the law must rule.

The inclusion of fundamental rights in the (last!) requirement of the Commission Rule of Law Framework could sound as a reference to a 'thick' conception of the rule of law. ${ }^{157}$ However, defining the first and the foremost principle of the rule of law (legality) as including 'a transparent, accountable, democratic, and pluralistic process for enacting the law', clearly refers to a 'thin' conception of the rule of law, and a 'procedural' conception, where the requirements of impartial courts and ef-

\footnotetext{
149 Case C-147/13 Spain v Council of the European Union ECLI:EU:C:2015:299, para 79.

150 Case C- 212/80 Amministrazione delle Finanze dello Stato $v$ Salumi ECLI:EU:C:1981:270, para 9.

151 Case C-46/87 Hoechst AG v Commission ECLI:EU:C:1989:337, para 33.

152 Case C-286/12 Commission v Hungary ECLI:EU:C:2012:687, para 68.

153 Case C-101/78 Granaria BV v Hoofdproduktschap ECLI:EU:C:1979:38, para 5.

Case C-167/73 Commission v France ECLI:EU:C:1974:35, para 35.

155 Case C-441/17 Commission v Poland ECLI:EU:C:2018:255, para 102.

156 Case C-496/99 Commission v CAS Succhi di Frutta ECLI:EU:C:2004:236, para 63.

157 Commission (n 51) para 2.
} 
fective judicial review serve to guarantee the enforcement of whatever is expressed by the law. The same Commission states that the precise content of the principles and standards stemming from the rule of law might vary at national level, depending on each Member State's constitutional system. ${ }^{158}$ While the precise content of these requirements may vary from country to country, these requirements are common in respect of the Member States' constitutional system, which is safeguarded as an EU value, and found the rule of law of the EU institutions and Member States truly forming an EU conception of the rule of law.

With reference to the rule of law crises examined, it appears clear that the EU approach to the rule of law leans towards this direction of a 'thin' rule of law conception, also in respect of this issue. In the EU, the rule of law is considered compromised when national actors no longer respect the sovereignty of the law. The cases of Italy, Romania and Poland are self-explanatory. 'The law rules exclusively' principle means that all actors must obey the law, and that the only way to challenge it consists in changing it, rather than disregarding it, as required by the congruence principle of the rule of law. ${ }^{159}$ The EU rule of law does not ask for national law to bear some specific content - the rule of the good law ${ }^{160}$ - but rather expects formal requirements for rulings, and for the rulings to be respected. ${ }^{161}$ Therefore, it seems that the EU rule of law encompasses both the aforementioned core principles: the law should be obeyed, and the law should be such that it can be obeyed. Both could, however, be brought back under the same umbrella term: the rule of law. Here, the term 'rule' should be considered in the same way that Kant addresses the term 'reason'. The 'rule' is both the rule that defines, shapes and characterises the law and the explanation, exploitation, and enforcement of the same law. The law rules because it is ruled by these standards, and these standards exist because they are inherent in the concept of law ruling. Actually, going back to Aristotle's conceptualisation, the rule of law ideal is expressed in the terms of nomon archein, ${ }^{162}$ meaning the sovereignty of the law, which encompasses both the ideals of law being sovereign and effective, and that the 'sovereign must be lawful and not manned'. ${ }^{163}$

However, allegiance to a 'thin' rule of law ideal does not mean to accede to an entirely positivist concept of the law. The rule of law is not

\footnotetext{
158 ibid, para 4.

159 Cass R Sunstein and Adrian Vermule, 'The Morality of Administrative Law' (2018) 131 Harvard Law Review 1958.

160 Joseph Raz, The Authority of Law: Essays on Law and Morality (Clarendon Press 1979) 227.

161 Wojciech Sadurski, 'The Other Anniversary' (2017) 13(3) European Constitutional Law Review 424.

162 Aristotle, Politics, Book III (H Rackham, tr 1932) 1287a.

163 Waldron (n 95) 7.
} 
mere legality or obedience to the current law, it includes the possibility to lawfully challenge the law. This makes up the third core principle of the rule of law: there are requirements for framing, requirements for enforcing, and requirements for judging the law itself. There should be procedural requirements for which courts, operating according to standards of due process, will offer an impartial forum where the law can be judged according to legal parameters. This holds true for any legal system, but it is even truer for the EU, as it is a multi-level system: the EU rule of law needs to have national courts which apply the EU law autonomously, even when conflicting with national law; at the same time, the EU rule of law needs the CJEU to judge both EU law and national law; last, the constitutional courts in the EU Member States are needed for challenging the EU law itself. ${ }^{164}$ For this reason, the downgrading of the independence and effectiveness of the judiciary in Hungary and Poland represents a serious problem for the whole EU on account of depriving their citizens of a rule of law forum. Ultimately, the CJEU is firm in stating that every person has the right to a fair hearing in an independent tribunal, as provided by the EU Charter. ${ }^{165}$ The very existence of effective judicial review is especially of the essence for the rule of law. ${ }^{166}$ In more detail, the CJEU holds that the operation of the rule of law requires a clear organisational and functional separation of the executive from the judiciary. ${ }^{167}$ The guarantee of independence, which is inherent in the task of adjudication, is expressly required at the level of the Member States. ${ }^{168}$ A system of justice that does not provide these kinds of guarantees could not be said to be consistent with the concept of a rule of law state in the EU. ${ }^{169}$ This procedural conception of the rule of law is reinforced by the statement that separation of powers characterises the rule of law, and that the judiciary has its own autonomy. ${ }^{170}$ In the recent case Associação

\footnotetext{
164 Case C-294/83 Les Verts ECLI:EU:C:1986:166, para 23.

165 Case C-174/98 Netherlands $v$ Commission ECLI:EU:C:2000: 1, para 14.

166 Case C-64/16 Associação Sindical dos Juízes Portugueses v Tribunal de Contas ECLI:EU:C:2018:117, para 36.

167 Case C-477/16 Ruslanas Kovalkovas ECLI:EU:C:2016:861, para 36.

168 Associação Sindical dos Juizes Portugueses (n 162) para 42.

169 Case C-216/18 PPU Minister for Justice and Equality ECLI:EU:C:2018:586, para 22.

170 In more detail, the concept of independence presupposes, in particular, that the body concerned exercises its judicial functions wholly autonomously, without being subject to any hierarchical constraint or subordinated to any other body and without taking orders or instructions from any source whatsoever. In this way, it is protected against external interventions or pressure liable to impair the independent judgment of its members and to influence their decisions. With regard to the independence of the judiciary, thus, the concept of the rule of law is at risk with regard to the judiciary when the legislative measure adopted affects the judiciary alone and there are not superior interests at stake. See Associação Sindical dos Juizes Portugueses (n 162) paras 44-50.
} 
Sindical, the CJEU clearly stated that Article 19 TEU - the affirmation of the rule of law through CJEU adjudication tasks - allows it to assess whether Member State judicial systems meet the standards of judicial independence in the EU, a standard not built of content provisions (eg adversarial or inquisitorial trial, jury or professional judge) but rather on a formal and procedural rule of law conception. In the EU context, Member States can adopt different legislative choices, also regarding important areas such as the judiciary, although not to the extent of disregarding the rule of law.

\section{Conclusions: between unity and union}

Conclusively, there is a guardian, or watchdog as many say, of the rule of law in Europe, which is the EU. ${ }^{171}$ This guardian acts when the rule of law is compromised, when the law does not rule and when its rule is unlawful, according to a 'thin' or procedural rule of law definition. ${ }^{172}$

It is thus appropriate to speak of THE rule of law in the EU and its Member States, since one rule of law is ruling them all. This rule of law is twofold: it is both a principle of unity, leading to a Unity of legislations, under the name of the rule of EU law, and a principle of union, leading instead towards a union of legislation, under the name of the EU rule of law. ${ }^{173}$ With regard to the areas covered by EU legislation, it is appropriate to invoke the rules of the EU law, as a principle of unity that does not tolerate deviations from what it prescribes, and sanctions them when they occur. Instead, it is a principle of union when we observe them from the perspective of the EU rule of law, whose aim is to ensure rule of law conditions all across the EU, no matter the type, scope or object of the law that is ruling. It is by relying on this profile of union that the EU may intervene also in areas where there is no unity, due to the absence of EU legislation. Indeed, even in areas where the EU has no competence, national rules must be exercised consistently with the principles governing the EU. ${ }^{174}$ Here, the aim of the EU is not to harmonise the rule of law, but to have the law, the national one too, enforced, even against its own Member States.

\footnotetext{
171 The role of the guardian in the EU is particularly entrusted to the Commission, which has the control of both the major mechanism for detecting and sanctioning rule of law violations, namely Art 7 TEU and Art 258 TFUE. However, with respect to both mechanisms, the Commission works as an introductory body: it is not up to the Commission to establish a violation of EU principles or of its provisions; in one case, the Council and the European Council, with the consent of the European Parliament, and in the other case the CJEU, affirms the existence of the risk or of the breach, and may define the penalties.

172 Sadurski (n 15) 1.

173 Nadia Urbinati, 'Representative Democracy and Its Critics' in Sonia Alonso, John Keane and Wolfgang Merkel (eds), The Future of Representative Democracy (CUP 2012) 45.

174 Case C-246/89 Commission v United Kingdom ECLI:EU:C:1991:375.
} 
Through Article 7 TEU, there is an EU law conferred competence and a relative tool for protecting this aspect of the rule of law principle proclaimed in Article 2 TEU: this is because 'The scope of Article 7 is not confined to areas covered by Union law [...]. Article 7 is horizontal and general in scope'. ${ }^{175}$ It would indeed be paradoxical to confine the EU's possibilities of action to the areas covered by EU law only, asking it to ignore serious breaches in areas of national jurisdiction. ${ }^{176}$ Additionally, Article 7 TEU does not focus on what is breached, but the manner in which it is breached and how it occurs: all deviations from law-making and its enforcement are relevant to the extent that they represent a serious risk of a breach or a breach in itself, concerning which the Commission refers to the 'purpose' and the 'result' of the breach. If a Member State breaches the fundamental values in a manner sufficiently serious to be covered by Article $7 \mathrm{TEU}$, this is likely to undermine the foundations of the EU, whatever the field in which the breach occurs. ${ }^{177}$ Article 7 TEU thus confers a power to the EU over matters that relate to a Member State's activity outside the scope of EU law. It is an emblematic representation of Union being more than the mere Unity of legislations. It cannot be said more clearly: the EU rule of law encompasses more than the rules of EU law. ${ }^{178}$ The EU rule of law is thus fundamental to the EU, more than the rules of EU law, which are not unchallengeable and unchallenged per se: national constitutional courts give several indications in this direction. However, they do so in regard to the rules of EU law, not towards the EU rule of law. The EU rule of law instead encompasses the whole of the EU space and project: it underlies and informs the purpose, function and character of the EU. ${ }^{179}$ This is why the CJEU stresses the importance of the rule of law as a defining element of the EU's constitutional framework. ${ }^{180}$

The consequence of the identification of the EU rule of law as the core of the EU enterprise is its impact on the pluralist concept of the EU framework, according to the fact that the EU ought to be legally pluralist because it is socially pluralist. According to the pluralist understanding, there is no uniformity in the EU: foundational values are shared, but are expressed differently across the EU. Pluralism commands this composition, allowing each entity of a pluralist identity to achieve its own balance between crucial values in many areas, for example constricting or expanding the media space, keeping the judiciary and the executive apart or joining them

\footnotetext{
175 Commission (n 108) para 3.

176 ibid, para 8.

177 Theodore Konstadidnides, The Rule of Law in the European Union: The Internal Dimension (Hart Publishing 2017) 32.

178 Commission (n 108) 17.

179 Trevor RS Allan, Constitutional Justice: A Liberal Theory of the Rule of Law (OUP 2003) 4.

180 Case C-402/05 Kadi $v$ Council of the European Union ECLI:EU:C:2008:461, para 24.
} 
together, enacting or dismantling a judicial review, and so on. This is undoubtedly true, but these same areas have to be framed and enforced in the same way, that is, through the rule of law. Thus, in many areas, internal boundaries may arise within the EU: but, by judging on these boundaries, the EU rule of law encompasses them. National laws are not limits to the EU rule of law, but are simply internal boundaries in the space of the EU rule of law. ${ }^{181}$ They must be respected, but they are not out of reach of the EU rule of law: only a system where the laws respect certain parameters (the formal requirement), enforce the commands (the obedience requirement), and where they may be challenged (the procedural requirement) may set these internal boundaries, and only Member States' legal systems which comply with these parameters fall within the EU rule of law boundaries. Paraphrasing Von Bogdandy, when it comes to the rule of law, the EU legal space turns into an EU legal order. ${ }^{182}$ The rule of law in the EU context is fundamental since its presence does not allow a state to comply with its rules of law and at the same time disregard the rule of law. When this happens, being the rule of law common to the state and the EU, the EU is authorised to act in defence of that supranational community that is the EU rule of law, which allows a redefinition of the content of the community which stands to the extent its limits are recognized. ${ }^{183}$

Having Article 2 TEU and Article 7 TEU is something like a constitutional control by the EU, grounded on neither constitutional provisions nor substantive law - which is up to national constitutional courts or the ECtHR - but on the concept of the rule of law itself. Therefore, the duty of the EU to respect the national identity inherent in a Member State's political and constitutional structure is not a limit to the invocation of Article 7 TEU for dealing with threats to Article 2 TEU values: the rule of law is said to be 'common to the Member States' and, as such, does not belong to the scope of features covered by separate 'national identities'. Member States' constitutional identity has thus a meaning insofar as it complies with Article 2 and 7 TEU, the common values clause and the homogeneity clause, respectively. ${ }^{184}$

The EU promise is an open space where the law can be articulated and redefined in the course of debate, with the general and uncompromised guarantee that this law complies with certain parameters and, on

\footnotetext{
181 Hans Lindahl, Fault Lines of Globalization (OUP 2013) 174.

182 Armin Von Bogdandy, 'European Law Beyond "Ever Closer Union” Repositioning the Concept, Its Thrust and the ECJ's Comparative Methodology' (2016) 22(4) European Law Journal 519, 528.

183 Martii Koskenniemmi, The Gentle Civilizer of Nations (CUP 2004) 507.

184 Leonard Besselink, 'The Bite, the Bark and the Howl: Article 7 TEU and the Rule of Law Initiative' in András Jakab and Dimitry Kochenov (eds), The Enforcement of EU Law and Values: Ensuring Member States' Compliance (OUP 2017) 128.
} 
that basis and on that basis alone, it rules. Here, there is a legitimate source of appealing to the EU, particularly for its constitutionalisation process. Indeed, two classic authors - Dicey and Montesquieu - agreed that one precondition for the construction of federal entities is the political homogeneity of the Member States. ${ }^{185}$ More than this, they though that the Member States composing the federation must have the same political form of government. If a Member State became an autocracy, it would endanger the whole federation. This threat to the political homogeneity of the federation explains why most federations acknowledge the right of an intervention in the case of a change of regime within a Member State. ${ }^{186}$

Here, the intervention against Poland and Hungary, and against any other Member States threatening the EU political homogeneity, which in the EU is to be a rule of law Member State, is part of the EU constitutionalisation process towards a more structured federal entity. But the federalist authors envisaged another, subjective, condition for the building of a federal entity: the existence of a very peculiar sentiment among the peoples of the countries that they are supposed to bring together. They must desire Union, and they must not desire Unity. Unlike the Nation State, a Union of States desires and even fosters diversity and pluralism.

Member States are not destined to become another self in the European Union: Member States integrated in the EU may exhibit different legislative choices in many areas, as long as they comply with EU law where there is one, and provided they stay obedient to the Union principles where there is none. The EU as a political Union, where it is possible to democratically complain about, and fight for, the enactment or repeal of this or that piece of EU legislation, but where the rule of law is not questioned, would be a remarkable achievement. ${ }^{187}$

\section{(c) $(1) \Theta$}

This work is licensed under the Creative Commons Attribution - Non-Commercial - No Derivatives 4.0 International License.

Suggested citation: F Peirone, 'The Rule of Law in the EU: Between Union and Unity' (2019) 15 CYELP 57

185 Albert V Dicey, Introduction to the Study of the Law of the Constitution (first published 1885, Liberty Fund 1982) 21; Charles de Montesquieu, The Spirit of the Laws (first published 1748, CUP 1989) 131.

186 Olivier Beaud, 'Federation and Empire: About a Conceptual Distinction of Political Forms' (2018) 16(4) International Journal of Constitutional Law 1199-1206.

187 Anthony Arnull, 'The Rule of Law in the European Union' in Anthony Arnull and Daniel Wincott (eds), Accountability and Legitimacy in the European Union (OUP 2002) 254. 